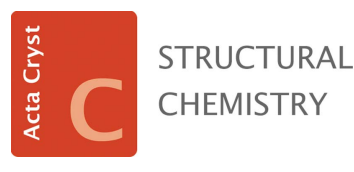

ISSN 2053-2296

Received 30 September 2016

Accepted 17 January 2017

Edited by D. L. Bryce, University of Ottawa, Canada

Keywords: NMR crystallography; solid-state NMR; dithianon; pyrimethanil; cocrystal; hydrogen bonding; $\mathrm{C}-\mathrm{H} \cdots \pi$ interactions; fungicides.

CCDC reference: 1507863

Supporting information: this article has supporting information at journals.iucr.org/c

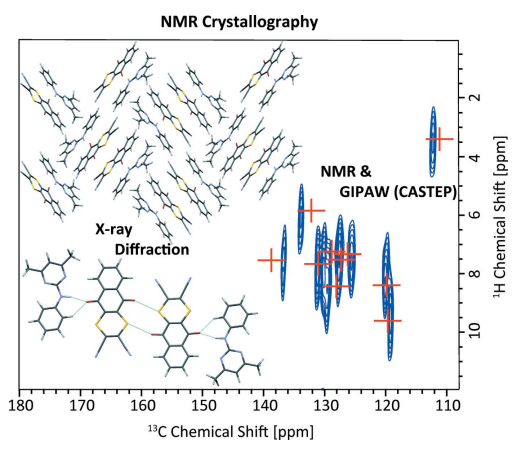

OPEN Ә ACCESS

\section{Single-crystal X-ray diffraction and NMR crystal- lography of a 1:1 cocrystal of dithianon and pyrimethanil}

\author{
Ann-Christin Pöppler, ${ }^{a, b}$ Emily K. Corlett, ${ }^{a, c}$ Harriet Pearce, ${ }^{\text {a,c }}$ Mark P. Seymour, ${ }^{d}$ \\ Matthew Reid, ${ }^{\text {d,e }}$ Mark G. Montgomery ${ }^{\mathrm{d}}$ and Steven P. Brown ${ }^{\mathrm{a} *}$ \\ ${ }^{\mathbf{a}}$ Department of Physics, University of Warwick, Coventry CV4 7AL, United Kingdom, ${ }^{\mathbf{b}}$ Department of Organic Chemistry, \\ University of Würzburg, 97074 Würzburg, Germany, 'Molecular Analytical Science Centre for Doctoral Training, \\ University of Warwick, Coventry CV4 7AL, United Kingdom, 'International Research Centre, Syngenta, Jealott's Hill, \\ Bracknell, Berkshire RG42 6EY, United Kingdom, and ${ }^{\mathbf{e}}$ Afton Chemical, London Road, Bracknell, Berkshire RG12 2UW, \\ United Kingdom. *Correspondence e-mail: s.p.brown@warwick.ac.uk
}

A single-crystal X-ray diffraction structure of a 1:1 cocrystal of two fungicides, namely dithianon (DI) and pyrimethanil (PM), is reported [systematic name: 5,10-dioxo-5 $H, 10 H$-naphtho[2,3-b][1,4]dithiine-2,3-dicarbonitrile-4,6-dimethyl$N$-phenylpyrimidin-2-amine (1/1), $\left.\mathrm{C}_{14} \mathrm{H}_{4} \mathrm{~N}_{2} \mathrm{O}_{2} \mathrm{~S}_{2} \cdot \mathrm{C}_{12} \mathrm{H}_{13} \mathrm{~N}_{2}\right]$. Following an NMR crystallography approach, experimental solid-state magic angle spinning (MAS) NMR spectra are presented together with GIPAW (gauge-including projector augmented wave) calculations of NMR chemical shieldings. Specifically, experimental ${ }^{1} \mathrm{H}$ and ${ }^{13} \mathrm{C}$ chemical shifts are determined from two-dimensional ${ }^{1} \mathrm{H}-{ }^{13} \mathrm{C}$ MAS NMR correlation spectra recorded with short and longer contact times so as to probe one-bond $\mathrm{C}-\mathrm{H}$ connectivities and longer-range $\mathrm{C} \cdots \mathrm{H}$ proximities, whereas $\mathrm{H} \cdots \mathrm{H}$ proximities are identified in a ${ }^{1} \mathrm{H}$ double-quantum (DQ) MAS NMR spectrum. The performing of separate GIPAW calculations for the full periodic crystal structure and for isolated molecules allows the determination of the change in chemical shift upon going from an isolated molecule to the full crystal structure. For the ${ }^{1} \mathrm{H}$ NMR chemical shifts, changes of 3.6 and $2.0 \mathrm{ppm}$ correspond to intermolecular $\mathrm{N}-\mathrm{H} \cdots \mathrm{O}$ and $\mathrm{C}-\mathrm{H} \cdots \mathrm{O}$ hydrogen bonding, while changes of -2.7 and $-1.5 \mathrm{ppm}$ are due to ring current effects associated with $\mathrm{C}-\mathrm{H} \cdots \pi$ interactions. Even though there is a close intermolecular S . . O distance of $3.10 \AA$, it is of note that the molecule-to-crystal chemical shifts for the involved sulfur or oxygen nuclei are small.

\section{Introduction}

With an increasing global population, limited availability of arable land, an increase in extreme weather events and growing pest resistance to certain existing agrochemical products, innovation in the agrochemical industry is as important as ever if we are to provide enough food for everyone. With lower usage rates, ease of use and more favourable toxicology profiles being important objectives, the search for and structure-based design of potential agrochemical products needs to become more efficient (Lamberth et al., 2013). One possibility in this regard is the usage of cocrystals formed between an active ingredient and coformers or other active ingredients via reversible noncovalent interactions. While this is an established procedure in the development of new active pharmaceutical ingredients, where it is used to increase the solubility and bioavailability (Blagden et al., 2007), there is also great potential to exploit cocrystals in the optimization and development of agrochemicals. For example, a reduced solubility could increase the agrochemical's resi- 
Table 1

Experimental details.

\begin{tabular}{ll}
\hline Crystal data & \\
Chemical formula & $\mathrm{C}_{14} \mathrm{H}_{4} \mathrm{~N}_{2} \mathrm{O}_{2} \mathrm{~S}_{2} \cdot \mathrm{C}_{12} \mathrm{H}_{13} \mathrm{~N}_{3}$ \\
$M_{\mathrm{r}}$ & 495.59 \\
Crystal system, space group & Monoclinic, $P 2_{1} / n$ \\
Temperature (K) & 100 \\
$a, b, c(\AA)$ & $7.1707(2), 22.8006(6), 13.8237(4)$ \\
$\beta\left({ }^{\circ}\right)$ & $97.047(3)$ \\
$V\left(\AA^{3}\right)$ & $2243.04(7)$ \\
$Z$ & 4 \\
Radiation type & $\mathrm{Cu} K \alpha$ \\
$\mu\left(\mathrm{mm}^{-1}\right)$ & 2.45 \\
Crystal size (mm) & $0.60 \times 0.10 \times 0.02$ \\
& \\
Data collection & Agilent Xcalibur Onyx Ultra \\
Diffractometer & Multi-scan $(C r y s A l i s ~ P R O ;$ \\
Absorption correction & Agilent, 2014) \\
& $0.596,1.000$ \\
$T_{\text {min }}, T_{\text {max }}$ & $5143,3160,2667$ \\
No. of measured, independent and & \\
observed $[I>2.0 \sigma(I)]$ reflections & 0.035 \\
$R_{\text {int }}$ & 58.9 \\
$\theta_{\text {max }}\left({ }^{\circ}\right)$ & 0.556 \\
(sin $\theta / \lambda)_{\text {max }}\left(\AA^{-1}\right)$ & \\
& \\
Refinement & \\
$R\left[F^{2}>2 \sigma\left(F^{2}\right)\right], w R\left(F^{2}\right), S$ & $0.045,0.094,0.98$ \\
No. of reflections & 3141 \\
No. of parameters & 109 \\
No. of restraints & 3 \\
$\mathrm{H}-$ atom treatment & $\mathrm{H}$ atoms treated by a mixture of \\
& independent and constrained \\
$\Delta \rho_{\text {max }}, \Delta \rho_{\text {min }}\left(\mathrm{e} \AA^{-3}\right)$ & refinement \\
\hline & $0.43,-0.37$ \\
\hline
\end{tabular}

Computer programs: CrysAlis PRO (Agilent, 2014), SUPERFLIP (Palatinus \& Chapuis, 2007), CRYSTALS (Betteridge et al., 2003), CAMERON (Watkin et al., 1996) and Mercury (Macrae et al., 2006).

dence time on the respective plant and multicomponent entities could improve the release profile (and thus absolute usage), as well as allow the simultaneous delivery of two or more active components. However, the design of suitable cocrystalline materials and prediction of their properties and formed cocrystal structures is far from being trivial. Some design strategies based on the hierarchy of intermolecular interactions (Aakeroy \& Salmon, 2005) or the assessment of the solubilities and saturation temperatures of the pure compounds to be included in a cocrystalline arrangement (ter Horst et al., 2009) are available as a guideline. However, if multiple and different hydrogen-bonding donors and acceptors are present in the molecules, a reliable prediction of the resulting structure becomes very difficult (Bhatt et al., 2009).

NMR crystallography, namely the combination of experimental solid-state magic angle spinning (MAS) NMR with calculation of NMR parameters, is finding important application to moderately sized organic molecules (Harris, 2004; Elena et al., 2006; Harris et al., 2009; Bonhomme et al., 2012). We present here an NMR crystallography analysis of the 1:1 cocrystal of two fungicides, namely dithianon (DI) and pyrimethanil (PM). Specifically, following a preparation protocol in Sowa et al. (2013), a single-crystal X-ray diffraction structure determination is reported, with this structure (after DFT geometry optimization) providing the input for a calculation, using the GIPAW (gauge-including projector augmented wave) method (Pickard \& Mauri, 2001; Yates et al., 2007), of the NMR chemical shieldings. The computational analysis is complemented by the recording of $1 \mathrm{D}$ (one-dimensional) and 2D (two-dimensional) experimental ${ }^{1} \mathrm{H}$ and ${ }^{13} \mathrm{C}$ MAS NMR spectra. Building upon studies of pharmaceutical cocrystals by such an NMR crystallography investigation (Tatton et al., 2013; Dudenko et al., 2013; Stevens et al., 2014; Kerr et al., 2015; Sardo et al., 2015; Luedeker et al., 2016), we present here the application of this approach to an agrochemical cocrystal.

\section{Experimental and computational details}

\subsection{Sample preparation}

The DI-PM cocrystal was prepared according to method VII in point [0041] of Sowa et al. (2013), i.e. dry dithianon and pyrimethanil (both solids) were mixed thoroughly in a 1:1 molar ratio $(0.5 \mathrm{~g}$ of pyrimethanil) and kept at $323 \mathrm{~K}$ under agitation. After a couple of hours, the powdery product had changed to a dark-olive-green colour.<smiles>N#Cc1sc2c(=O)c3ccccc3c(=O)c=2sc1C#N</smiles><smiles>Cc1cc(C)nc(Nc2ccccc2)n1</smiles>

\section{DI-PM}

2.2. Single-crystal X-ray diffraction: structure solution and refinement

Crystal data, data collection and structure refinement details are summarized in Table 1 . The $\mathrm{H}$ atoms were all located in a difference map, but those attached to $\mathrm{C}$ atoms were repositioned geometrically. The $\mathrm{H}$ atoms were initially refined with soft restraints on the bond lengths and angles to regularize their geometry $[\mathrm{C}-\mathrm{H}=0.93-0.98 \AA$ and $\mathrm{N}-\mathrm{H}=$ $0.86-0.89 \AA$, and with $U_{\text {iso }}(\mathrm{H})=1.2-1.5 U_{\text {eq }}$ (parent)], after which the positions were refined with riding constraints (Cooper et al., 2010).

\subsection{Solid-state NMR}

1D ${ }^{1} \mathrm{H}$ MAS and $1 \mathrm{D}{ }^{13} \mathrm{C}$ cross polarization (CP) MAS experiments were performed on a Bruker Avance III spectrometer operating at ${ }^{1} \mathrm{H}$ and ${ }^{13} \mathrm{C}$ Larmor frequencies of 600 and $150.9 \mathrm{MHz}$, respectively, using a $1.3 \mathrm{~mm} \mathrm{HXY}\left({ }^{1} \mathrm{H}\right.$ MAS) or a $4 \mathrm{~mm} \mathrm{HX}\left({ }^{13} \mathrm{C} C P\right.$ MAS) Bruker probe. In all cases, a ${ }^{1} \mathrm{H}$ $90^{\circ}$ pulse duration of $2.5 \mu$ s was used. $2 \mathrm{D}^{1} \mathrm{H}_{-}{ }^{13} \mathrm{C}$ HETCOR experiments were performed on a Bruker Avance III spectrometer, using a $4 \mathrm{~mm} \mathrm{HXY}$ probe in double-resonance mode. In the HETCOR pulse sequence, the following phase cycling was employed: ${ }^{1} \mathrm{H} 90^{\circ}$ pulse $\left(90^{\circ} 270^{\circ}\right),{ }^{13} \mathrm{C} 180^{\circ}$ pulse $\left(2\left\{0^{\circ}\right\} 2\left\{180^{\circ}\right\}\right),{ }^{13} \mathrm{C} \mathrm{CP}$ contact pulse $\left(4\left\{0^{\circ}\right\} 4\left\{180^{\circ}\right\} 4\left\{90^{\circ}\right\}\right.$ $\left.4\left\{270^{\circ}\right\}\right)$, receiver $\left(0^{\circ} 180^{\circ} 0^{\circ} 180^{\circ} 180^{\circ} 0^{\circ} 180^{\circ} 0^{\circ} 90^{\circ} 270^{\circ} 90^{\circ}\right.$ $270^{\circ} 270^{\circ} 90^{\circ} 270^{\circ} 90^{\circ}$ ). For CP, a 70 to $100 \%$ ramp (Metz et al., 1994) on the ${ }^{1} \mathrm{H}$ channel was used for the $\mathrm{CP}$ contact time. During acquisition of a ${ }^{13} \mathrm{C}$ FID, SPINAL64 (Fung et al., 2000) 


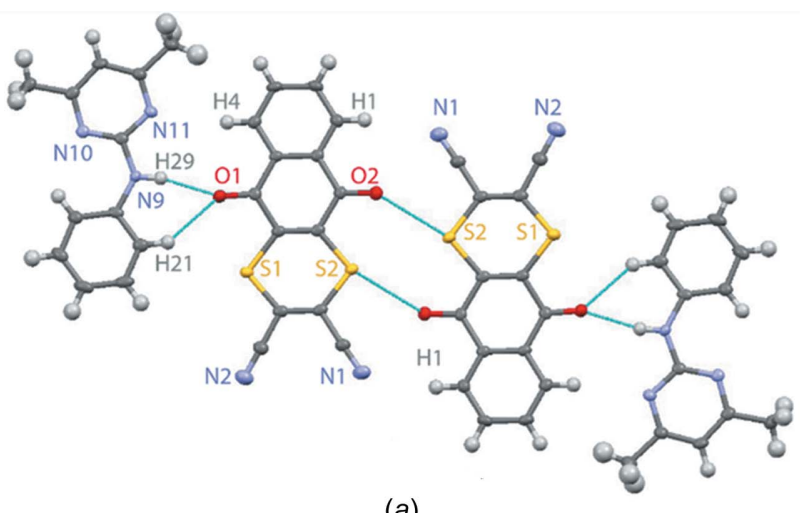

(a)
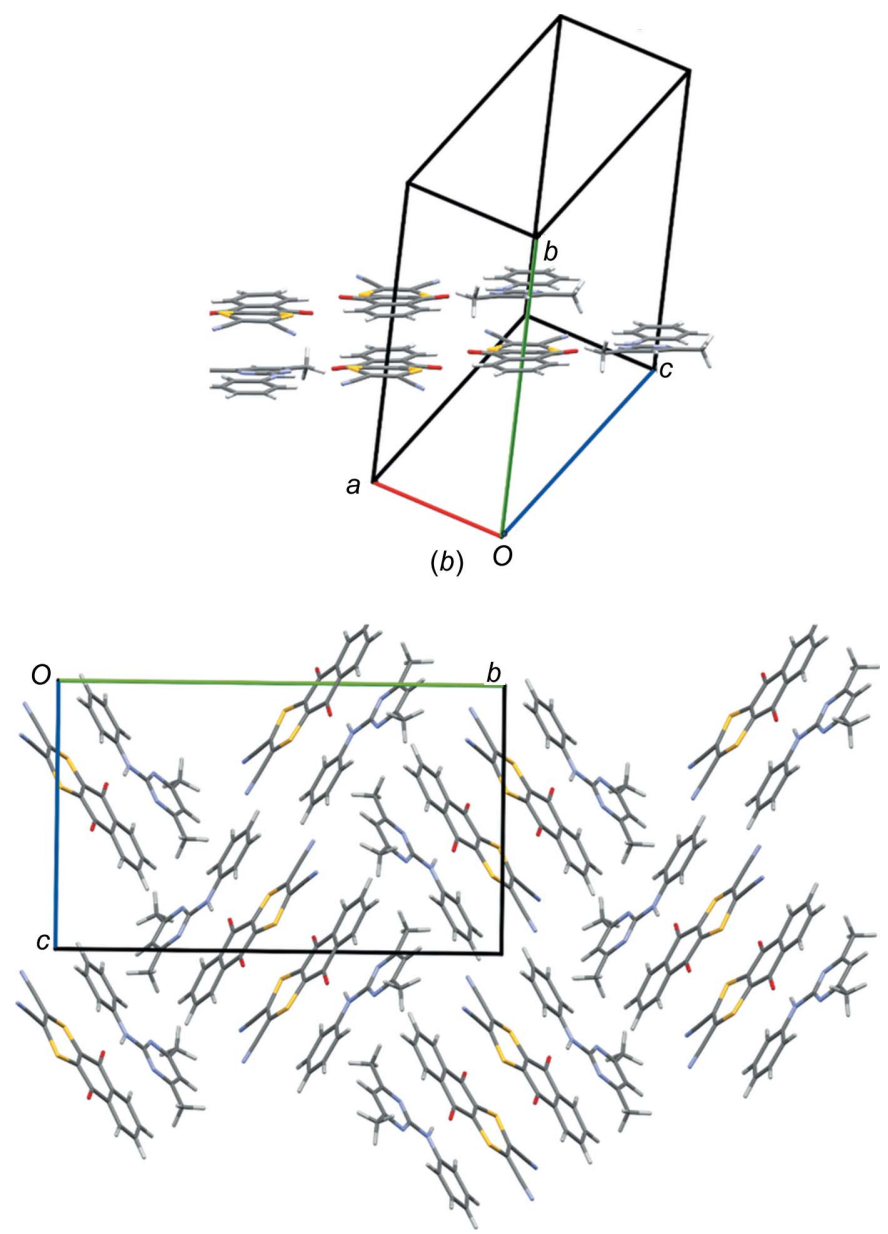

(c)

Figure 1

Representations of the crystal structure of the DI-PM cocrystal, showing (a) the intermolecular interactions within a 'chain' of molecules, with displacement ellipsoids drawn at the $50 \%$ probability level, $(b)$ the packing of two chains of molecules as 'layers' and (c) the 'zigzag' arrangement of chains (viewed along the crystallographic $a$ axis). In parts $(b)$ and $(c)$, the unit cell is shown, indicating the $a, b$ and $c$ unit-cell axes.

${ }^{1} \mathrm{H}$ heteronuclear decoupling was applied with a pulse duration of $5.9 \mu$ s at a nutation frequency of $100 \mathrm{kHz}$. A 2D ${ }^{1} \mathrm{H}$ DQ experiment with BABA recoupling (Sommer et al., 1995; Schnell et al., 1998) was performed on a Bruker Avance III spectrometer operating at a ${ }^{1} \mathrm{H}$ Larmor frequency of $700 \mathrm{MHz}$ using a 1.3 mm HXY Bruker probe. A 16-step phase cycle was used to select $\Delta p= \pm 2$ on the DQ excitation block and $\Delta p=$ -1 on the $z$-filter $90^{\circ}$ pulse, where $p$ is the coherence order. In all 2D experiments, the States-TPPI method was used to achieve sign discrimination in $F_{1} \cdot{ }^{13} \mathrm{C}$ and ${ }^{1} \mathrm{H}$ chemical shifts are referenced with respect to TMS using L-alanine at natural abundance as an external reference: $177.8 \mathrm{ppm}$ for the ${ }^{13} \mathrm{C}$ carboxylate resonance and $1.1 \mathrm{ppm}$ for the ${ }^{1} \mathrm{H}$ methyl resonance. All experiments were performed at room temperature, though frictional effects due to MAS increase the actual sample temperature (Langer et al., 1999).

\subsection{DFT calculations}

Calculations were performed using CASTEP (Clark et al., 2005; Academic Release Version 8.0) and employed the PBE exchange-correlational functional (Perdew et al., 1996). For both geometry optimization and NMR shielding calculations, a plane-wave basis set with ultrasoft pseudopotentials (Vanderbilt, 1990) with a maximum plane-wave cut-off energy of $700 \mathrm{eV}$ was used. A Monkhorst-Pack grid of minimum sample spacing $0.05 \times 2 \pi \AA^{-1}$ was used to take integrals over the Brillouin zone. Geometry optimization was performed with the unit-cell parameters fixed, starting from the singlecrystal X-ray structure. The positions of the 208 atoms in the unit cell $\left(Z=4, Z^{\prime}=1\right)$ were relaxed and periodic boundary conditions were applied. The space group $P 2_{1} / n$ was preserved. All distances and angles stated in the main text of this article are for the geometry-optimized crystal structure. Note also that the geometry optimization within CASTEP causes a relabelling of the atoms - in this article, we use the CASTEP numbering; see Fig. S1 in the Supporting information for a comparison with the numbering employed in the crystallographic CIF file. The GIPAW method (Pickard \& Mauri, 2001; Yates et al., 2007) was utilized for the NMR chemical-shielding calculations, which were performed on the geometry-optimized structure. For the isolated molecule calculations, a single molecule (either DI or PM) from the fully geometry optimized structure is kept in the unit cell, whose dimensions are also increased by $\sim 5 \AA$ in each direction - the NMR shieldings are then calculated without any further geometry optimization.

\section{Results and discussion}

\subsection{Single-crystal X-ray diffraction structure}

The single-crystal X-ray diffraction structure of the DI-PM cocrystal is schematically represented in Fig. 1. As shown in Fig. 1(a), a chain of molecules is held together by $\mathrm{N}-\mathrm{H} \cdots \mathrm{O}$ and $\mathrm{C}-\mathrm{H} \cdots \mathrm{O}$ hydrogen bonds (between DI and PM molecules) and by putative S. .O interactions (Burling \& Goldstein, 1992) between two DI molecules; note that the relative strengths of these interactions is investigated below (see §3.5) using GIPAW calculations of NMR chemical shieldings. The further packing of two chains of molecules as 'layers' and a 'zigzag' arrangement of chains are shown in Figs. 1(b) and $1(c)$, respectively. As can be seen from the representation along the crystallographic $a$ axis in Fig. 1(c), the packing is 


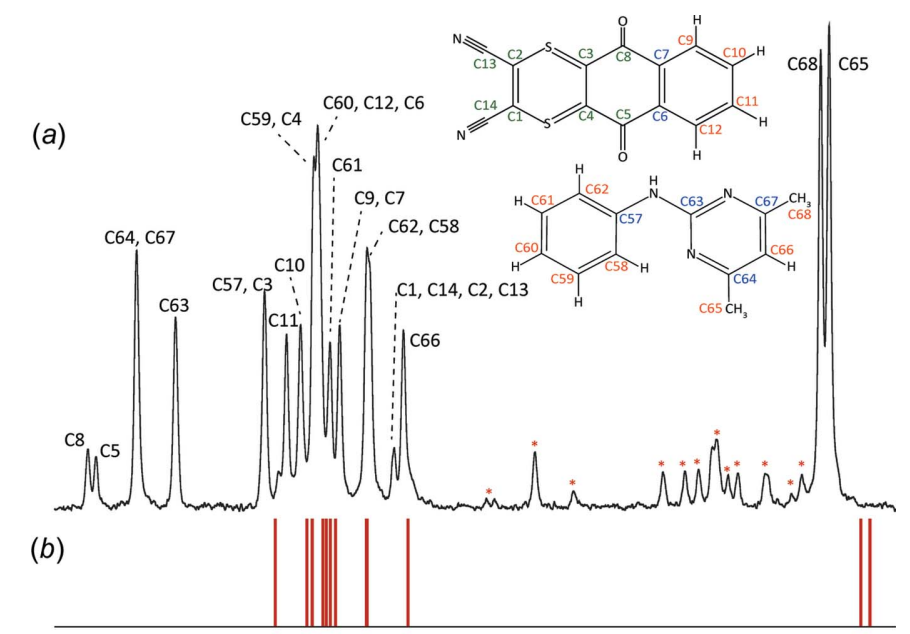

(c)

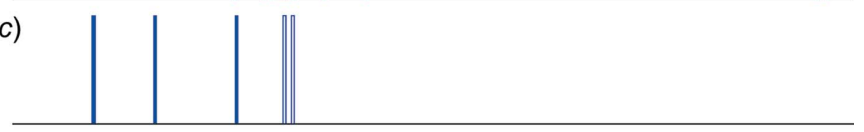

(d)

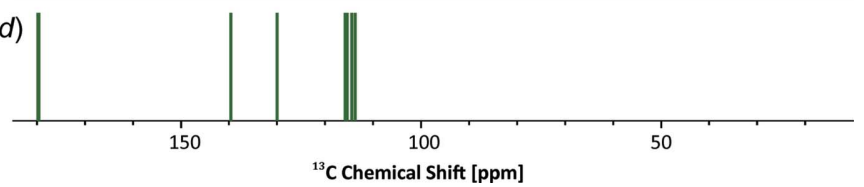

Figure 2

(a) $\mathrm{A}^{1} \mathrm{H}(600 \mathrm{MHz})-{ }^{13} \mathrm{C} \mathrm{CP}$ MAS $(12.5 \mathrm{kHz})$ NMR spectrum of the DIPM cocrystal (* denote spinning sidebands), together with $(b)-(d)$ stick spectra corresponding to calculated (GIPAW) ${ }^{13} \mathrm{C}$ chemical shifts (see Table 2). Separate stick spectra are presented according to whether correlation peaks corresponding to $(b)$ direct $\mathrm{C}-\mathrm{H}$ bonds or $(c)$ longerrange $\mathrm{C} \cdots \mathrm{H}$ proximities are observed in the ${ }^{1} \mathrm{H}-{ }^{13} \mathrm{C} 2 \mathrm{D}$ spectra presented in Fig. 4, or $(d)$ where no experimental correlation peaks are observed. In the CP MAS experiment, a contact time of $1.4 \mathrm{~ms}$ was used and 1024 transients were co-added for a recycle delay of $57 \mathrm{~s}$.

based on assemblies of blocks of four molecules; four molecules (PM-DI-DI-PM) are arranged in a layer (Fig. 1a), forming a block that is perpendicular to an adjacent block of four molecules, thus building up the 'zigzag' arrangement.

\subsection{Experimental and calculated ${ }^{13} \mathrm{C}$ chemical shifts}

Fig. 2 presents a ${ }^{13} \mathrm{C} \mathrm{CP}$ MAS NMR 1D spectrum (Fig. 2a) of the DI-PM cocrystal, together with three stick spectra (Figs. $2 b, 2 c$ and $2 d$ ) that represent ${ }^{13} \mathrm{C}$ chemical shifts calculated using the GIPAW method for the DI-PM crystal structure. Specifically, the calculated ${ }^{13} \mathrm{C}$ chemical shifts are presented in three groups according to whether they correspond to direct one-bond $\mathrm{C}-\mathrm{H}$ connectivities (Fig. $2 b$, red labels) or nonprotonated $\mathrm{C}$ atoms (Figs. $2 c$ and $2 d$, blue and green labels, respectively). The distinction between Figs. 2(c) and $2(d)$ corresponds to whether cross peaks corresponding to a longer-range $\mathrm{C} \cdots \mathrm{H}$ proximity are observed in ${ }^{1} \mathrm{H}-{ }^{13} \mathrm{C} 2 \mathrm{D}$ correlation spectra (see $§ 3.4)$.

\subsection{One- and two-dimensional ${ }^{1} \mathrm{H}$ MAS NMR spectra}

Figs. 3(a) and 3(b) present ${ }^{1} \mathrm{H}$ NMR spectra of the DI-PM cocrystal recorded at a fast MAS frequency of $60 \mathrm{kHz}$; specifically, a one-pulse one-dimensional spectrum in Fig. 3(a), together with vertical lines corresponding to calculated
Table 2

Comparison of calculated (GIPAW) ${ }^{a}$ and experimental ${ }^{13} \mathrm{C}$ and ${ }^{1} \mathrm{H}$ NMR chemical shifts (in ppm) in the DI-PM cocrystal ${ }^{b}$.

\begin{tabular}{|c|c|c|c|c|c|}
\hline & Atom label & & & ${ }^{1} \mathrm{H}$ & \\
\hline $\mathrm{C}$ & $\mathrm{H}$ & $\delta_{\text {calc }}$ & $\delta_{\text {expt }}$ & $\delta_{\text {calc }}$ & $\delta_{\text {expt }}$ \\
\hline $\mathrm{C} 65$ & $\mathrm{H} 22 / \mathrm{H} 23 / \mathrm{H} 24^{c}$ & 15.3 & 23.9 & 1.8 & 1.9 \\
\hline C68 & $\mathrm{H} 26 / \mathrm{H} 27 / \mathrm{H} 28^{c}$ & 17.2 & 25.7 & 2.0 & 2.0 \\
\hline C66 & H25 & 111.5 & 112.6 & 3.4 & 4.0 \\
\hline $\mathrm{C} 1$ & - & 113.8 & $114.4^{d}$ & - & - \\
\hline $\mathrm{C} 14$ & - & 114.5 & $114.4^{d}$ & - & - \\
\hline $\mathrm{C} 2$ & - & 115.5 & $114.4^{d}$ & - & - \\
\hline $\mathrm{C} 13$ & - & 115.9 & $114.4^{d}$ & - & - \\
\hline $\mathrm{C} 58$ & H17 & 120.1 & 119.4 & 9.7 & 9.1 \\
\hline C62 & $\mathrm{H} 21$ & 120.2 & 120.3 & 8.4 & 8.0 \\
\hline C9 & H1 & 126.7 & 125.7 & 7.4 & 7.4 \\
\hline $\mathrm{C} 7$ & $H 1^{e}$ & 126.8 & 125.7 & 7.4 & 7.4 \\
\hline C61 & $\mathrm{H} 20$ & 127.7 & 127.7 & 7.6 & 7.4 \\
\hline $\mathrm{C} 12$ & $\mathrm{H} 4$ & 128.5 & 129.8 & 8.5 & 8.2 \\
\hline C6 & $H 4^{e}$ & 128.6 & 129.8 & 8.5 & 8.2 \\
\hline C60 & H19 & 129.3 & 130.2 & 7.3 & 7.8 \\
\hline $\mathrm{C} 4$ & - & 130.1 & $131.1^{d}$ & - & - \\
\hline C59 & H18 & 131.5 & 131.2 & 7.7 & 7.7 \\
\hline $\mathrm{C} 10$ & $\mathrm{H} 2$ & 132.6 & 133.9 & 5.9 & 6.2 \\
\hline $\mathrm{C} 11$ & $\mathrm{H} 3$ & 139.2 & 136.8 & 7.6 & 7.7 \\
\hline C57 & $H 21, H 17, H 29$ & 138.5 & 141.5 & $8.4,9.7,10.5$ & 8.9 \\
\hline $\mathrm{C} 3$ & - & 139.7 & $141.4^{d}$ & - & _- \\
\hline C63 & $H 29$ & 155.5 & 160.1 & 10.5 & 9.1 \\
\hline C67 & H26/H27/H28, H25 & 168.2 & 168.2 & $2.0,3.4$ & 2.8 \\
\hline C64 & H22/H23/H24, H25 & 168.4 & 168.2 & $1.8,3.4$ & 2.8 \\
\hline $\mathrm{C} 5$ & - & 179.7 & $176.5^{d}$ & - & - \\
\hline $\mathrm{C} 8$ & - & 179.9 & $178.2^{d}$ & _- & - \\
\hline
\end{tabular}

Notes: (a) calculated isotropic chemical shifts are determined from calculated chemical shieldings according to $\delta_{\text {calc }}=\sigma_{\text {ref }}-\sigma_{\text {calc }}$, where $\sigma_{\text {ref }}$ equals $30.0 \mathrm{ppm}$ for ${ }^{1} \mathrm{H}$ and $163.2 \mathrm{ppm}$ for ${ }^{13} \mathrm{C}$. (b) $\mathrm{H}$-atom labels and calculated and experimental ${ }^{1} \mathrm{H}$ chemical shifts are presented in normal font for direct one-bond $\mathrm{C}-\mathrm{H}$ connectivities, while longer-range $\mathrm{C} \cdots \mathrm{H}$ proximities (corresponding to cross peaks observed in the ${ }^{1} \mathrm{H}-{ }^{13} \mathrm{C}$ spectra presented in Figs. $4 b$ and $4 c$ ) are presented in italics. (c) For $\mathrm{CH}_{3}$ groups, the calculated ${ }^{1} \mathrm{H}$ chemical shifts correspond to the average over the three $\mathrm{H}$ atoms. (d) Experimental chemical shifts taken from the ${ }^{13} \mathrm{C}$ CP MAS spectrum (Fig. $2 a$ ) since no cross peaks are observed in the ${ }^{1} \mathrm{H}-{ }^{13} \mathrm{C}$ spectra presented in Figs. $4(b)$ and $4(c)$. (e) Note that the $\mathrm{C} 7-\mathrm{H} 1$ and $\mathrm{C} 6-\mathrm{H} 4$ cross peaks due to longer-range $\mathrm{C} \cdots \mathrm{H}$ proximities cannot be distinguished from the $\mathrm{C} 9-\mathrm{H} 1$ and $\mathrm{C} 12-\mathrm{H} 4$ cross peaks due to one-bond $\mathrm{C}-\mathrm{H}$ connectivities - in the stick spectrum in Fig. 2(c), open bars denote the calculated (GIPAW) $\mathrm{C} 7$ and $\mathrm{C} 6{ }^{13} \mathrm{C}$ chemical shifts.

(GIPAW) ${ }^{1} \mathrm{H}$ chemical shifts, as well as a 2D DQ spectrum in Fig. 3(b). In addition, Fig. 3(c) presents a ${ }^{1} \mathrm{H}-{ }^{13} \mathrm{C} 2 \mathrm{D}$ correlation spectrum of the DI-PM cocrystal; note that this spectrum has been rotated through $90^{\circ}$ from its usual representation such that the direct $\left({ }^{13} \mathrm{C}\right)$ dimension is vertical. In this way, it is possible to directly compare (see vertical dashed lines) ${ }^{1} \mathrm{H}$ chemical shifts of peaks in the ${ }^{1} \mathrm{H}-{ }^{13} \mathrm{C}$ (Fig. 3c) and ${ }^{1} \mathrm{H}$ DQ 2D (Fig. 3b) and ${ }^{1} \mathrm{H} 1 \mathrm{D}$ (Fig. 3a) spectra. Two separate spectral regions are presented in Fig. 3(c) corresponding to (top) the methyl resonances at a ${ }^{13} \mathrm{C}$ chemical shift close to $25 \mathrm{ppm}$ and (bottom) the aromatic $\mathrm{CH}$ resonances with ${ }^{13} \mathrm{C}$ chemical shifts between 110 and $140 \mathrm{ppm}$.

The ${ }^{1} \mathrm{H}-{ }^{13} \mathrm{C}$ correlation spectrum in Fig. 3(c) was recorded using a short $\mathrm{CP}$ contact time of $100 \mu$ s to transfer magnetization from ${ }^{1} \mathrm{H}$ to ${ }^{13} \mathrm{C}$, such that cross peaks correspond to one-bond $\mathrm{C}-\mathrm{H}$ connectivities. The spreading of the resonances into two dimensions in Fig. 3(c) allows the identification of two and ten resolved cross peaks for the $\mathrm{CH}_{3}$ and aromatic $\mathrm{CH}$ groups, respectively. The value of such a ${ }^{1} \mathrm{H}-{ }^{13} \mathrm{C}$ correlation spectrum in resolving and assigning the experimental ${ }^{1} \mathrm{H}$ chemical shifts is thus evident. Table 2 lists the calculated (GIPAW) and experimental ${ }^{13} \mathrm{C}$ chemical shifts 

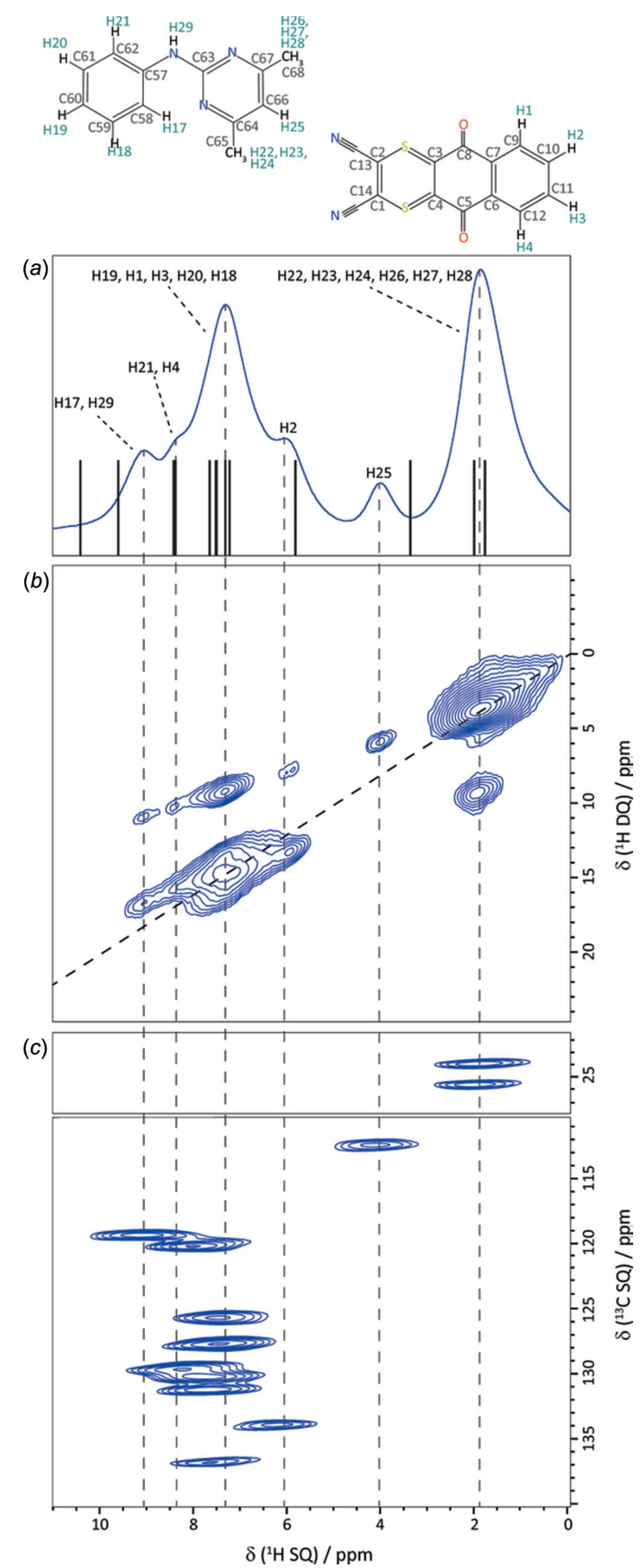

Figure 3

MAS NMR spectra of the DI-PM cocrystal, showing (a) a ${ }^{1} \mathrm{H}(600 \mathrm{MHz})$ MAS $(60 \mathrm{kHz})$ one-pulse spectrum (16 transients were co-added for a recycle delay of $15 \mathrm{~s}),(b)$ a $2 \mathrm{D}{ }^{1} \mathrm{H}(700 \mathrm{MHz})$ DQ MAS $(60 \mathrm{kHz})$ spectrum (the dashed diagonal line indicates the $F_{1}=2 F_{2}$ DQ-SQ diagonal) recorded using one rotor period of BABA recoupling (32 transients were co-added for each of $200 t_{1}$ FIDs using a recycle delay of $6 \mathrm{~s}$, corresponding to a total experiment time of $12 \mathrm{~h}$ ) and $(c)$ a ${ }^{1} \mathrm{H}$ $(500 \mathrm{MHz})-{ }^{13} \mathrm{C}$ HETCOR MAS $(12.5 \mathrm{kHz})$ spectrum recorded using FSLG ${ }^{1} \mathrm{H}$ homonuclear decoupling in $t_{1}$ and a short $\mathrm{CP}$ transfer duration of $100 \mu \mathrm{s}$ (104 transients were co-added for each of $128 t_{1}$ FIDs using a recycle delay of $6 \mathrm{~s}$, corresponding to a total experimental time of $22 \mathrm{~h}$ ). The vertical lines in part (a) correspond to calculated (GIPAW) ${ }^{1} \mathrm{H}$ chemical shifts. For the ${ }^{1} \mathrm{H}-{ }^{13} \mathrm{C}$ NMR spectrum in part $(c)$, two separate spectral regions are presented corresponding to methyl and aromatic $\mathrm{C}-$ $\mathrm{H}$ groups; note that this spectrum has been rotated through $90^{\circ}$ from its usual representation [the ${ }^{13} \mathrm{C}$ dimension corresponds to direct $\left(t_{2}\right)$ acquisition]. The base contour level is at (b) $7 \%$ and (c) $20 \%$ of the maximum peak height. (sorted in order of increasing chemical shift). For directly bonded $\mathrm{C}-\mathrm{H}$ connectivities, $\mathrm{H}$-atom labels and calculated (GIPAW) and experimental ${ }^{1} \mathrm{H}$ chemical shifts are presented in normal font.

Fig. 4 compares ${ }^{1} \mathrm{H}-{ }^{13} \mathrm{C}$ correlation spectra recorded with three different $\mathrm{CP}$ contact times of $100 \mu \mathrm{s}$ (Fig. 4a), $500 \mu \mathrm{s}$ (Fig. 4b) and $1 \mathrm{~ms}$ (Fig. 4c); Fig. 4(a) is a copy of Fig. 3(c), but presented in the normal orientation, i.e. with the direct $\left({ }^{13} \mathrm{C}\right)$ dimension horizontal. It is evident that additional cross peaks are observed for longer CP contact times - these correspond to longer-range $\mathrm{C} \cdot \mathrm{H}$ proximities (see italics font in Table 2). Notably, cross peaks are observed at ${ }^{13} \mathrm{C}$ chemical shifts of 141.5 (atom C57), 160.1 (atom C63) and 168.2 ppm (atoms C64 and C67); these all correspond to intramolecular proximities within the dithianon molecule, i.e. C57 with H17 (9.1 ppm, $2.16 \AA), \mathrm{H} 21$ (8.0 ppm, $2.16 \AA)$ and H29 (9.1 ppm, $2.06 \AA)$, C63 with $\mathrm{H} 29$ (9.1 ppm, $2.01 \AA)$, C64 and C67 with $\mathrm{H} 25$ (4.0 ppm, 2.16 and $2.17 \AA$ ) and $\mathrm{CH}_{3}$ protons (1.9 and $2.0 \mathrm{ppm}$, nearest distance $2.14 \AA$ ). Of most interest is the (160.1 ppm, $9.1 \mathrm{ppm}$ ) cross peak, which thus enables the determination of the $\mathrm{NH}^{1} \mathrm{H}$ chemical shift.

With all the ${ }^{1} \mathrm{H}$ chemical shifts assigned, let us re-examine the ${ }^{1} \mathrm{H}$ DQ MAS spectrum in Fig. 3(b). In such a spectrum, cross peaks are observed in the DQ dimension at the sum of the two single-quantum (SQ) frequencies if there is a close proximity (typically up to $3.5 \AA$; Brown, 2007, 2012) between the corresponding two $\mathrm{H}$ atoms (a full listing of $\mathrm{H} \cdots \mathrm{H}$ proximities under $3.5 \AA$ for the DI-PM cocrystal is given in Table S1 of the Supporting information). Consider the two lowest-ppm aromatic $\mathrm{CH}$ protons $\mathrm{H} 25(4.0 \mathrm{ppm})$ and $\mathrm{H} 2$ (6.2 ppm) for which distinct ${ }^{1} \mathrm{H}$ resonances are resolved in the ${ }^{1} \mathrm{H}$ SQ dimension. For H25, the only DQ peak is at $4.0+2.0=$ $6.0 \mathrm{ppm}$ with the $\mathrm{CH}_{3}$ protons, since $\mathrm{H} 25$ is sandwiched between two methyl-group substituents on the PM molecule. For $\mathrm{H} 2$, there is a DQ peak at $6.2+7.5=13.7$ ppm corresponding to the intramolecular $\mathrm{H} \cdots \mathrm{H}$ proximity with the neighbouring $\mathrm{H} 1$ (7.4 ppm, $2.50 \AA$ ) and $\mathrm{H} 3$ (7.7 ppm, $2.47 \AA$ ) DI aromatic $\mathrm{CH}$ protons, as well as a DQ peak at $6.2+2.0=$ $8.2 \mathrm{ppm}$ due to intermolecular proximities to the $\mathrm{PM} \mathrm{CH}_{3} \mathrm{H}$ atoms (H23, H24, H28 and $\mathrm{H} 22$ at 2.90, 3.03, 3.12 and $3.12 \AA$, respectively). Considering the high-ppm region, DQ cross peaks for the overlapping PI NH H29 (9.1 ppm) and aromatic $\mathrm{CH}$ H17 (9.1 ppm) resonances are observed at $9.1+7.7=$ $16.8 \mathrm{ppm}$ for intramolecular $\mathrm{H} 29 \cdots \mathrm{H} 21$ (2.21 $\AA$ ) and H17 $\cdots H 18(2.50 \AA)$ proximities, as well as at $9.1+2.0=$ $11.1 \mathrm{ppm}$ for intermolecular proximities to PM methyl-group protons (closest distances of $\mathrm{H} 17 \cdots \mathrm{H} 26=2.48 \AA$ and $\mathrm{H} 29 \cdot \mathrm{H} 24=2.64 \AA$ ). For the other overlapping $\mathrm{CH}$ aromatic resonances, cross peaks due to intramolecular proximities with other $\mathrm{CH}$ aromatic resonances, as well as intermolecular proximities to the methyl protons, are also observed.

3.4. Comparison of experimental and calculated ${ }^{1} \mathrm{H}$ and ${ }^{13} \mathrm{C}$ chemical shifts

In the ${ }^{1} \mathrm{H}-{ }^{13} \mathrm{C}$ correlation spectra presented in Fig. 4, red crosses correspond to calculated (GIPAW) ${ }^{13} \mathrm{C}$ and ${ }^{1} \mathrm{H}$ 

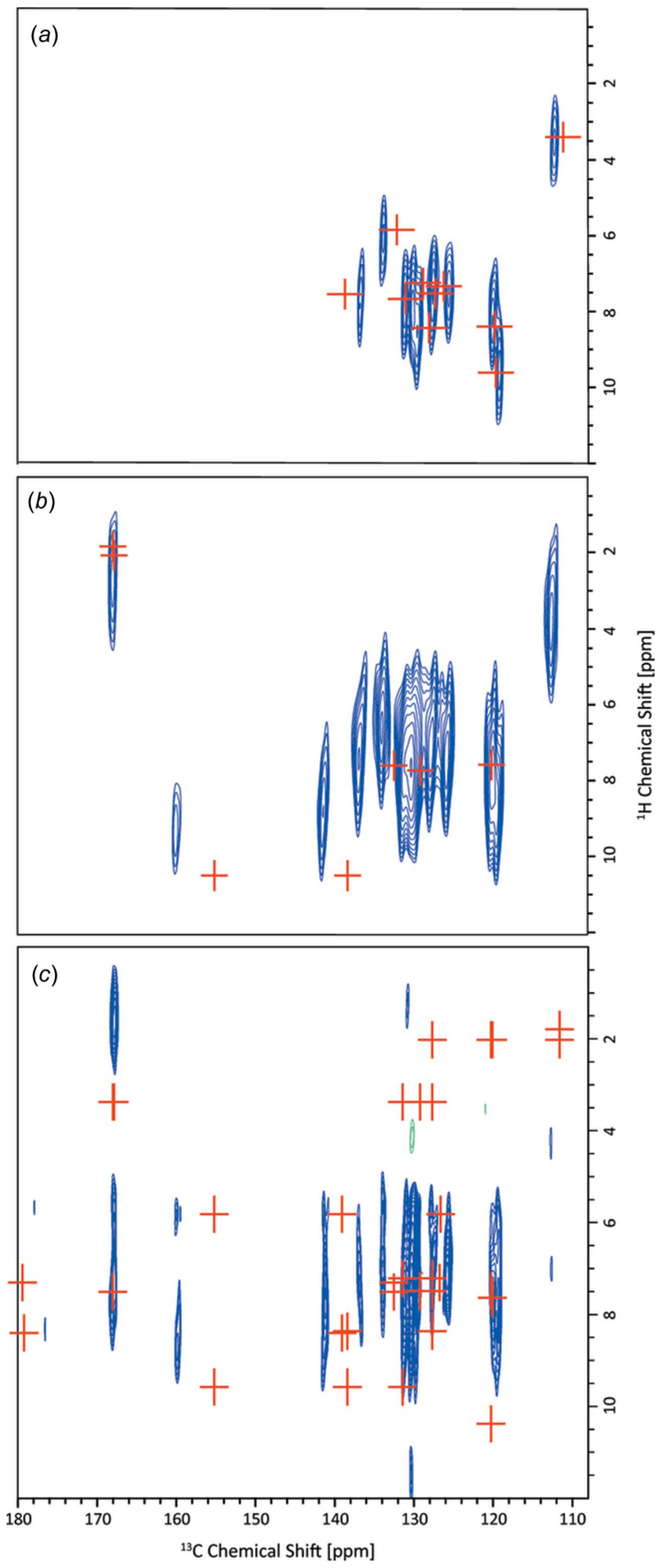

Figure 4

${ }^{1} \mathrm{H}(500 \mathrm{MHz})-{ }^{13} \mathrm{C}$ HETCOR MAS $(12.5 \mathrm{kHz})$ spectra of the DI-PM cocrystal recorded using FSLG ${ }^{1} \mathrm{H}$ homonuclear decoupling (Bielecki et $a l ., 1989)$ in $t_{1}$ with a CP transfer duration of $(a) 100 \mu \mathrm{s},(b) 500 \mu \mathrm{s}$ and $(c)$ $1 \mathrm{~ms}$. The spectrum in part $(a)$ is repeated from Fig. 3(c). 104 transients were co-added for each of $(b) 128$ or $(c) 90 t_{1}$ FIDs using a recycle delay of (b) 6 or $(c) 5.5 \mathrm{~s}$, corresponding to a total experimental time of $(b) 22$ or (c) $14 \mathrm{~h}$. The scaling factor in $F_{1}$ was determined to be $(a)$ and $(b) 1.80$ or (c) 1.73 . The base contour level is at (a) 20, (b) 13 and (c) $25 \%$ of the maximum peak height. Red crosses correspond to GIPAW-calculated ${ }^{1} \mathrm{H}$ and ${ }^{13} \mathrm{C}$ chemical shifts (see Table 2) for $(a)$ one-bond $\mathrm{C}-\mathrm{H}$ bonds and (b) and (c) C $\cdots$ H proximities between (b) 1.2 and $2.2 \AA$, and (c) 2.2 and $3.0 \AA$ A. chemical shifts. Specifically, in Fig. 4(a), red crosses correspond to direct $\mathrm{C}-\mathrm{H}$ one-bond connectivities $(\mathrm{C}-\mathrm{H}$ distances under $1.2 \AA$ ), while in Figs. 4(b) and 4(c), red crosses are presented for $\mathrm{C}-\mathrm{H}$ proximities between 1.2 and $2.2 \AA$ (Fig. $4 b$ ), and between 2.2 and $3.0 \AA$ (Fig. 4c). We comment here on the level of agreement between experimental and calculated (GIPAW) chemical shifts. Starting with a consideration of the aromatic $\mathrm{CH}$ moieties (see Fig. $4 a$ and Table 2), the discrepancy between experiment and calculation is within $2 \mathrm{ppm}$ for the ${ }^{13} \mathrm{C}$ chemical shifts (except for $\mathrm{C} 11$, where the difference is $2.4 \mathrm{ppm}$ ); this corresponds to the established observation that the discrepancy is within $1 \%$ of the chemical shift range ( $\sim 200 \mathrm{ppm}$ for ${ }^{13} \mathrm{C}$ chemical shifts of diamagnetic molecules). For the ${ }^{1} \mathrm{H}$ chemical shifts, while most are within the usual $0.3 \mathrm{ppm}$, some exhibit slightly larger discrepancies, notably $0.6 \mathrm{ppm}$ for atoms $\mathrm{H} 17$ and $\mathrm{H} 25$.

For the two $\mathrm{CH}_{3}$ groups (see Figs. 2 and $3 a$, and Table 2), there is excellent agreement for the ${ }^{1} \mathrm{H}$ chemical shifts (within $0.1 \mathrm{ppm}$ ), whereas the calculated ${ }^{13} \mathrm{C}$ chemical shifts are both $8.5 \mathrm{ppm}$ lower than the experimental values, although the experimental difference in ${ }^{13} \mathrm{C}$ chemical shifts between atoms C65 and C68 of $1.8 \mathrm{ppm}$ is reproduced by the calculation (difference of $1.9 \mathrm{ppm}$ ). The explanation for this is well known, namely, the gradient of a plot of experimental ${ }^{13} \mathrm{C}$ chemical shifts against calculated shielding deviates slightly from -1 (Harris et al., 2007; Ashbrook \& McKay, 2016), such that calculated ${ }^{13} \mathrm{C}$ chemical shifts are too low and too high compared to experiment for low-ppm and high-ppm resonances if, as here (see Fig. 2), the gradient is constrained to -1 and a single reference shielding is used. An alternative approach would be to use different reference shieldings for different regions of the spectrum (Webber, Emsley et al., 2010).

Returning to the ${ }^{1} \mathrm{H}$ chemical shifts, the biggest discrepancy is for the $\mathrm{NH}$ proton $(\mathrm{H} 29)$, where the calculated ${ }^{1} \mathrm{H}$ chemical shift of $10.5 \mathrm{ppm}$ is $1.4 \mathrm{ppm}$ higher than the experimental value of $9.1 \mathrm{ppm}$. Such a large difference is explained by a known temperature dependence (the experimental ${ }^{1} \mathrm{H}$ chemical shift increases upon reducing the temperature) for hydrogen-bonded protons (Brown et al., 2001; Pickard et al., 2007; Webber, Elena et al., 2010), considering that the calculation corresponds to $0 \mathrm{~K}$.

\subsection{Calculated molecule-to-crystal changes in chemical shifts}

For cases such as the DI-PM cocrystal in this article, an NMR crystallography study is able to provide new insight by means of a comparison of chemical shifts calculated for the full crystal structure with those calculated for an isolated molecule (as extracted from the geometry-optimized crystal structure) (Yates et al., 2005; Schmidt et al., 2006; Mafra et al., 2012). Specifically, a molecule-to-crystal difference in chemical shift is indicative of a combination of intermolecular interactions, notably hydrogen bonding and ring currents due to $\mathrm{C}-\mathrm{H} \cdots \pi$ interactions, whereby the latter can be separately quantified by means of the nucleus independent chemical shift (NICS) 
Table 3

Comparison of experimental ${ }^{1} \mathrm{H}$ chemical shifts with calculated ${ }^{a}$ (GIPAW) values (all in ppm) for the DI-PM cocrystal for the full crystal structure and an isolated dithianon or pyrimethanil molecule.

\begin{tabular}{|c|c|c|c|c|}
\hline Atom & $\delta_{\exp }$ & $\delta_{\text {crystal }}$ & $\delta_{\text {molecule }}$ & $\Delta \delta_{\text {crystal-molecule }}$ \\
\hline H1 & 7.4 & 7.4 & 7.8 & -0.4 \\
\hline $\mathrm{H} 2$ & 6.2 & 5.9 & 7.4 & -1.5 \\
\hline H3 & 7.7 & 7.6 & 7.4 & 0.2 \\
\hline $\mathrm{H} 4$ & 8.2 & 8.5 & 7.8 & 0.7 \\
\hline H17 & 9.1 & 9.7 & 9.2 & 0.5 \\
\hline H18 & 7.7 & 7.7 & 7.0 & 0.7 \\
\hline H19 & 7.8 & 7.3 & 6.6 & 0.7 \\
\hline $\mathrm{H} 20$ & 7.4 & 7.6 & 7.0 & 0.6 \\
\hline $\mathrm{H} 21$ & 8.0 & 8.4 & 6.4 & 2.0 \\
\hline $\mathrm{H} 22 / 23 / 24^{b}$ & 1.9 & 1.8 & 1.9 & -0.1 \\
\hline $\mathrm{H} 25$ & 4.0 & 3.4 & 6.1 & -2.7 \\
\hline $\mathrm{H} 26 / 27 / 28^{b}$ & 2.0 & 2.0 & 1.8 & 0.2 \\
\hline H29 & 9.1 & 10.5 & 6.9 & 3.6 \\
\hline
\end{tabular}

Notes: $(a)$ calculated isotropic chemical shieldings are determined from calculated chemical shieldings according to $\delta_{\text {calc }}=\sigma_{\text {ref }}-\sigma_{\text {calc }}$, where $\sigma_{\text {ref }}$ equals $30.0 \mathrm{ppm} ;(b)$ for $\mathrm{CH}_{3}$ groups, the calculated ${ }^{1} \mathrm{H}$ chemical shifts correspond to the average over the three $\mathrm{H}$ atoms.

(von Ragué Schleyer et al., 1996; Sebastiani, 2006; Uldry et al., 2008; Mafra et al., 2012). Consider Table 3, which presents the change in ${ }^{1} \mathrm{H}$ chemical shift upon going from an isolated

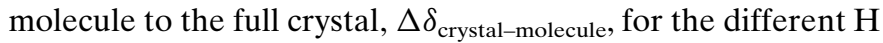
atoms in the DI-PM cocrystal. The largest positive change of $3.6 \mathrm{ppm}$ is observed for the $\mathrm{NH}(\mathrm{H} 29)$ atom that is involved in an intermolecular $\mathrm{N}-\mathrm{H} \cdots \mathrm{O}$ hydrogen bond to atom $\mathrm{O} 1$ (see Fig. $1 a$; the $\mathrm{N} \cdots \mathrm{O}$ and $\mathrm{H} \cdots \mathrm{O}$ distances are 2.95 and $1.96 \AA$, respectively, with a $162^{\circ} \mathrm{N}-\mathrm{H} \cdots \mathrm{O}$ angle). Interestingly, $\Delta \delta_{\text {crystal-molecule }}=2.0 \mathrm{ppm}$ for the aromatic $\mathrm{CH} \mathrm{H} 21$ atom, for which Fig. 1( $a$ ) identifies an intermolecular $\mathrm{C}-\mathrm{H} \cdots \mathrm{O}$ socalled weak hydrogen-bonding (Desiraju \& Steiner, 1999; Yates et al., 2005; Uldry et al., 2008) interaction (the C. .O and $\mathrm{H}$. . O distances are 3.24 and $2.35 \AA$, respectively, with a $138^{\circ}$ $\mathrm{C}-\mathrm{H} \cdots \mathrm{O}$ angle). The other $\mathrm{H}$ atoms, for which the magnitude of $\Delta \delta_{\text {crystal-molecule }}$ exceeds $1 \mathrm{ppm}$, are $\mathrm{H} 25(-2.7 \mathrm{ppm})$ and $\mathrm{H} 2(-1.6 \mathrm{ppm})$; as shown in Fig. 5, these marked changes

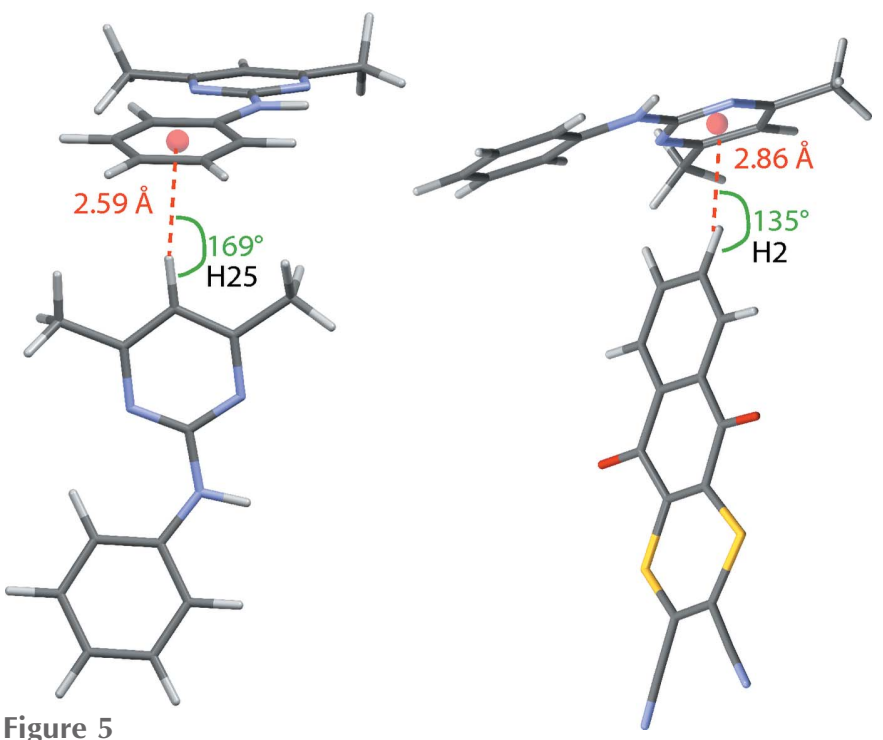

Figure 5

Schematic representations showing $\mathrm{C}-\mathrm{H} \cdots \pi$ interactions for aromatic atoms $(a) \mathrm{H} 25$ and $(b) \mathrm{H} 2$.
Table 4

Comparison of calculated (GIPAW) NMR chemical shieldings (in ppm) for the DI-PM cocrystal for the full crystal structure and an isolated dithianon or pyrimethanil molecule.

\begin{tabular}{lrrr}
\hline Atom & $\sigma_{\text {molecule }}$ & $\sigma_{\text {crystal }}$ & $\sigma_{\text {crystal-molecule }}$ \\
\hline N1 & -106.4 & -88.9 & 17.5 \\
N2 & -107.2 & -88.9 & 18.3 \\
N9 & 98.9 & 91.4 & -7.4 \\
N10 & -30.1 & -33.0 & -2.9 \\
N11 & -44.5 & -42.4 & 2.1 \\
O1 & -363.4 & -265.9 & 97.5 \\
O2 & -345.3 & -322.2 & 23.1 \\
S1 & 330.7 & 305.6 & -25.1 \\
S2 & 333.8 & 320.6 & -13.2 \\
\hline
\end{tabular}

in the ${ }^{1} \mathrm{H}$ chemical shift are a consequence of ring current effects associated with the proton pointing towards the centre of a six-membered aromatic ring of a nearby PM molecule in a $\mathrm{C}-\mathrm{H} \cdots \pi$ interaction, as has been noted previously in a number of other cases (Brouwer et al., 2008; Mafra et al., 2012; Brown, 2012).

In the above discussion in $\S 3.1$, a close $S$. . O distance, equal to $3.10 \AA$, between the $\mathrm{O} 2$ and $\mathrm{S} 2$ atoms of neighbouring DI molecules was noted; this is less than the sum of the van der Waals radii (3.32 ̊) (Beno et al., 2015; Zhang et al., 2015). Indeed, there is a growing literature discussing S. .O interactions (Burling \& Goldstein, 1992; Iwaoka et al., 2002; Beno et al., 2015). While we have not carried out ${ }^{17} \mathrm{O}$ or ${ }^{33} \mathrm{~S}$ solidstate NMR experiments as part of this study, an NMR crystallography approach enables the effect of such a putative $\mathrm{S}$...O interaction on the oxygen and sulfur NMR chemical shieldings to be investigated by means of the GIPAW calculation that reports on all nuclei in the solid-state structure. An inspection of Table 4 shows that it is interesting that $\Delta \delta_{\text {crystal-molecule }}$ (note that this is the negative of the difference in calculated absolute shielding, with the latter being stated in Table 4) is much larger for O1 (-98 ppm), which is involved in a $\mathrm{N}-\mathrm{H} \cdots \mathrm{O}$ intermolecular hydrogen bonding, as compared to that for $\mathrm{O} 2(-23 \mathrm{ppm})$. Moreover, the change for S2 $(13 \mathrm{ppm})$ is less than that for S1 (25 ppm), with both changes being small, though there is limited information on the range of experimentally observed solid-state NMR ${ }^{33} \mathrm{~S}$ chemical shifts (Hansen et al., 2008). We conclude that even though there is a close intermolecular S...O distance of $3.10 \AA$ in the DI-PM cocrystal, there is not a marked effect on the calculated NMR chemical shieldings for the $\mathrm{O} 2$ and S2 nuclei.

\section{Summary}

In summary, we have presented here an NMR crystallography study of an agrochemical cocrystal. Specifically in combination with a GIPAW calculation of the NMR shieldings, ${ }^{1} \mathrm{H}-{ }^{13} \mathrm{C} 2 \mathrm{D}$ correlation spectra enable the resolution and assignment of the $\mathrm{NH}$, aromatic $\mathrm{CH}$ and methyl resonances for the DI-PM cocrystal, while specific intra- and intermolecular $\mathrm{H} \cdots \mathrm{H}$ proximities are identified in a ${ }^{1} \mathrm{H}$ DQ MAS spectrum. The performing of separate GIPAW calculations for the full crystal 
structure and isolated DI and PM molecules yields the change in the NMR chemical shift upon going from the molecule to the crystal structure, thus allowing the quantitation of specific $\mathrm{N}-\mathrm{H} \cdots \mathrm{O}, \mathrm{C}-\mathrm{H} \cdots \mathrm{O}$ and $\mathrm{C}-\mathrm{H} \cdots \pi$ interactions.

\section{Acknowledgements and funding information}

ACP was supported by a Feodor Lynen Research Fellowship of the Alexander von Humboldt Foundation and a Newton International Fellowship of the Royal Society. EC and HP acknowledge funding from the Molecular Analytical Sciences Centre for Doctoral Training (EPSRC grant EP/L015307/1). We thank Peter Howe (Syngenta) for helpful discussions. Computational facilities were provided by the MidPlus Regional Centre of Excellence for Computational Science, Engineering and Mathematics, under EPSRC grant EP/ K000128/1, and the University of Warwick Scientific Computing Research Technology Platform. The $700 \mathrm{MHz}$ NMR spectrometer was partially funded from the European Research Council under the European Union's Seventh Framework Programme (FP/2007-2013)/ERC Grant Agreement 639907 (for Dr J. R. Lewandowski, Department of Chemistry, University of Warwick). The experimental and calculated data for this study are provided as a supporting data set from WRAP, the Warwick Research Archive Portal, at http://wrap.warwick.ac.uk/85381.

\section{References}

Aakeroy, C. B. \& Salmon, D. J. (2005). CrystEngComm, 7, 439-448. Agilent (2014). CrysAlis PRO. Agilent Technologies Ltd, Yarnton, Oxfordshire, England.

Ashbrook, S. E. \& McKay, D. (2016). Chem. Commun. 52, 7186-7204.

Beno, B. R., Yeung, K. S., Bartberger, M. D., Pennington, L. D. \& Meanwell, N. A. (2015). J. Med. Chem. 58, 4383-4438.

Betteridge, P. W., Carruthers, J. R., Cooper, R. I., Prout, K. \& Watkin, D. J. (2003). J. Appl. Cryst. 36, 1487.

Bhatt, P. M., Azim, Y., Thakur, T. S. \& Desiraju, G. R. (2009). Cryst. Growth Des. 9, 951-957.

Bielecki, A., Kolbert, A. C. \& Levitt, M. H. (1989). Chem. Phys. Lett. 155, 341-346.

Blagden, N., de Matas, M., Gavan, P. T. \& York, P. (2007). Adv. Drug Deliv. Rev. 59, 617-630.

Bonhomme, C., Gervais, C., Babonneau, F., Coelho, C., Pourpoint, F., Azais, T., Ashbrook, S. E., Griffin, J. M., Yates, J. R., Mauri, F. \& Pickard, C. J. (2012). Chem. Rev. 112, 5733-5779.

Brouwer, D. H., Alavi, S. \& Ripmeester, J. A. (2008). Phys. Chem. Chem. Phys. 10, 3857-3860.

Brown, S. P. (2007). Prog. Nucl. Magn. Reson. Spectrosc. 50, 199-251. Brown, S. P. (2012). Solid State Nucl. Magn. Reson. 41, 1-27.

Brown, S. P., Zhu, X. X., Saalwachter, K. \& Spiess, H. W. (2001). J. Am. Chem. Soc. 123, 4275-4285.

Burling, F. T. \& Goldstein, B. M. (1992). J. Am. Chem. Soc. 114, 2313-2320.

Clark, S. J., Segall, M. D., Pickard, C. J., Hasnip, P. J., Probert, M. J., Refson, K. \& Payne, M. C. (2005). Z. Kristallogr. 220, 567-570.

Cooper, R. I., Thompson, A. L. \& Watkin, D. J. (2010). J. Appl. Cryst. 43, 1100-1107.

Desiraju, G. R. \& Steiner, T. (1999). In The Weak Hydrogen Bond in Structural Chemistry and Biology. Oxford University Press.

Dudenko, D. V., Yates, J. R., Harris, K. D. M. \& Brown, S. P. (2013). CrystEngComm, 15, 8797-8807.

Elena, B., Pintacuda, G., Mifsud, N. \& Emsley, L. (2006). J. Am. Chem. Soc. 128, 9555-9560.
Fung, B. M., Khitrin, A. K. \& Ermolaev, K. (2000). J. Magn. Reson. 142, 97-101.

Hansen, M. R., Brorson, M., Bildsoe, H., Skibsted, J. \& Jakobsen, H. J. (2008). J. Magn. Reson. 190, 316-326.

Harris, R. K. (2004). Solid State Sci. 6, 1025-1037.

Harris, R. K., Hodgkinson, P., Pickard, C. J., Yates, J. R. \& Zorin, V. (2007). Magn. Reson. Chem. 45, S174-S186.

Harris, R. K., Wasylishen, R. E. \& Duer, M. J. (2009). Editors. NMR Crystallography. Chichester: Wiley.

Horst, J. H. ter, Deij, M. A. \& Cains, P. W. (2009). Cryst. Growth Des. 9, 1531-1537.

Iwaoka, M., Takemoto, S. \& Tomoda, S. (2002). J. Am. Chem. Soc. 124, 10613-10620.

Kerr, H. E., Softley, L. K., Suresh, K., Nangia, A., Hodgkinson, P. \& Evans, I. R. (2015). CrystEngComm, 17, 6707-6715.

Lamberth, C., Jeanmart, S., Luksch, T. \& Plant, A. (2013). Science, 341, 742-746.

Langer, B., Schnell, I., Spiess, H. W. \& Grimmer, A. R. (1999). J. Magn. Reson. 138, 182-186.

Luedeker, D., Gossmann, R., Langer, K. \& Brunklaus, G. (2016). Cryst. Growth Des. 16, 3087-3100.

Macrae, C. F., Edgington, P. R., McCabe, P., Pidcock, E., Shields, G. P., Taylor, R., Towler, M. \& van de Streek, J. (2006). J. Appl. Cryst. 39, 453-457.

Mafra, L., Santos, S. M., Siegel, R., Alves, I., Paz, F. A. A., Dudenko, D. \& Spiess, H. W. (2012). J. Am. Chem. Soc. 134, 71-74.

Metz, G., Wu, X. L. \& Smith, S. O. (1994). J. Magn. Reson. Ser. A, 110, 219-227.

Palatinus, L. \& Chapuis, G. (2007). J. Appl. Cryst. 40, 786-790.

Perdew, J. P., Burke, K. \& Ernzerhof, M. (1996). Phys. Rev. Lett. 77, 3865-3868.

Pickard, C. J. \& Mauri, F. (2001). Phys. Rev. B 63, 245101.

Pickard, C. J., Salager, E., Pintacuda, G., Elena, B. \& Emsley, L. (2007). J. Am. Chem. Soc. 129, 8932-8933.

Ragué Schleyer, P. von, Maerker, C., Dransfeld, A., Jiao, H. \& van Eikema Hommes, N. J. R. (1996). J. Am. Chem. Soc. 118, 6317-6318.

Sardo, M., Santos, S. M., Babaryk, A. A., Lopez, C., Alkorta, I., Elguero, J., Claramunt, R. M. \& Mafra, L. (2015). Solid State Nucl. Magn. Reson. 65, 49-63.

Schmidt, J., Hoffmann, A., Spiess, H. W. \& Sebastiani, D. (2006). J. Phys. Chem. B, 110, 23204-23210.

Schnell, I., Lupulescu, A., Hafner, S., Demco, D. E. \& Spiess, H. W. (1998). J. Magn. Reson. 133, 61-69.

Sebastiani, D. (2006). ChemPhysChem, 7, 164-175.

Sommer, W., Gottwald, J., Demco, D. E. \& Spiess, H. W. (1995). J. Magn. Reson. Ser. A, 113, 131-134.

Sowa, C., Saxell, H. E. \& Vogel, R. (2013). EU Patent EP 2197278.

Stevens, J. S., Byard, S. J., Seaton, C. C., Sadiq, G., Davey, R. J. \& Schroeder, S. L. M. (2014). Phys. Chem. Chem. Phys. 16, 1150-1160.

Tatton, A. S., Pham, T. N., Vogt, F. G., Iuga, D., Edwards, A. J. \& Brown, S. P. (2013). Mol. Pharm. 10, 999-1007.

Uldry, A. C., Griffin, J. M., Yates, J. R., Perez-Torralba, M., Maria, M. D. S., Webber, A. L., Beaumont, M. L. L., Samoson, A., Claramunt, R. M., Pickard, C. J. \& Brown, S. P. (2008). J. Am. Chem. Soc. 130, 945-954.

Vanderbilt, D. (1990). Phys. Rev. B, 41, 7892.

Watkin, D. J., Prout, C. K. \& Pearce, L. J. (1996). CAMERON. Chemical Crystallography Laboratory, Oxford, England.

Webber, A. L., Elena, B., Griffin, J. M., Yates, J. R., Pham, T. N., Mauri, F., Pickard, C. J., Gil, A. M., Stein, R., Lesage, A., Emsley, L. \& Brown, S. P. (2010). Phys. Chem. Chem. Phys. 12, 6970-6983.

Webber, A. L., Emsley, L., Claramunt, R. M. \& Brown, S. P. (2010). J. Phys. Chem. A, 114, 10435-10442.

Yates, J. R., Pham, T. N., Pickard, C. J., Mauri, F., Amado, A. M., Gil, A. M. \& Brown, S. P. (2005). J. Am. Chem. Soc. 127, 10216-10220. Yates, J. R., Pickard, C. J. \& Mauri, F. (2007). Phys. Rev. B, 76, 024401. Zhang, X., Gong, Z., Li, J. \& Lu, T. (2015). J. Chem. Inf. Model. 55, 2138-2153. 


\section{supporting information}

Acta Cryst. (2017). C73, 149-156 [https://doi.org/10.1107/S2053229617000870]

Single-crystal X-ray diffraction and NMR crystallography of a 1:1 cocrystal of dithianon and pyrimethanil

\section{Ann-Christin Pöppler, Emily K. Corlett, Harriet Pearce, Mark P. Seymour, Matthew Reid, Mark}

\section{G. Montgomery and Steven P. Brown}

\section{Computing details}

Data collection: CrysAlis PRO (Agilent, 2014); cell refinement: CrysAlis PRO (Agilent, 2014); data reduction: CrysAlis PRO (Agilent, 2014); program(s) used to solve structure: SUPERFLIP (Palatinus \& Chapuis, 2007); program(s) used to refine structure: CRYSTALS (Betteridge et al., 2003); molecular graphics: CAMERON (Watkin et al., 1996) and Mercury (Macrae et al., 2006); software used to prepare material for publication: CRYSTALS (Betteridge et al., 2003).

5,10-Dioxo-5H,10H-naphtho[2,3-b][1,4] dithiine-2,3-dicarbonitrile-4,6-dimethyl- $N$-phenylpyrimidin-2-amine $(1 / 1)$

\section{Crystal data}

$\mathrm{C}_{14} \mathrm{H}_{4} \mathrm{~N}_{2} \mathrm{O}_{2} \mathrm{~S}_{2} \cdot \mathrm{C}_{12} \mathrm{H}_{13} \mathrm{~N}_{3}$

$M_{r}=495.59$

Monoclinic, $P 2_{1} / n$

Hall symbol: -P 2 yn

$a=7.1707(2) \AA$

$b=22.8006(6) \AA$

$c=13.8237$ (4) $\AA$

$\beta=97.047(3)^{\circ}$

$V=2243.04(7) \AA^{3}$

$Z=4$

\section{Data collection}

Agilent Xcalibur Onyx Ultra diffractometer

Mirror monochromator $\omega / 2 \theta$ scans

Absorption correction: multi-scan

(CrysAlis PRO; Agilent, 2014)

$T_{\min }=0.596, T_{\max }=1.000$

5143 measured reflections

\section{Refinement}

Refinement on $F^{2}$

Least-squares matrix: full

$R\left[F^{2}>2 \sigma\left(F^{2}\right)\right]=0.045$

$w R\left(F^{2}\right)=0.094$

$S=0.98$

3141 reflections
$F(000)=1024$

$D_{\mathrm{x}}=1.467 \mathrm{Mg} \mathrm{m}^{-3}$

$\mathrm{Cu} K \alpha$ radiation, $\lambda=1.54184 \AA$

Cell parameters from 2711 reflections

$\theta=5.0-62.6^{\circ}$

$\mu=2.45 \mathrm{~mm}^{-1}$

$T=100 \mathrm{~K}$

Plate, purple

$0.60 \times 0.10 \times 0.02 \mathrm{~mm}$

3160 independent reflections

2667 reflections with $I>2.0 \sigma(I)$

$R_{\text {int }}=0.035$

$\theta_{\max }=58.9^{\circ}, \theta_{\min }=3.2^{\circ}$

$h=-5 \rightarrow 7$

$k=-25 \rightarrow 25$

$l=-14 \rightarrow 15$

109 parameters

3 restraints

Primary atom site location: other

Hydrogen site location: difference Fourier map

$\mathrm{H}$ atoms treated by a mixture of independent and constrained refinement 


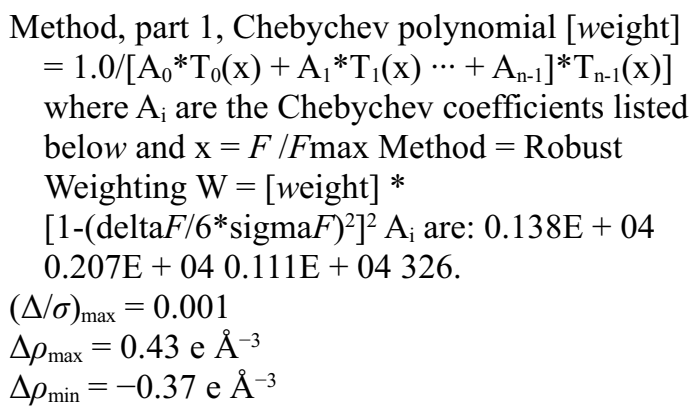

Special details

Experimental. The crystal was placed in the cold stream of an Oxford Cryosystems open-flow nitrogen cryostat (Cosier \& Glazer, 1986) with a nominal stability of $0.1 \mathrm{~K}$.

Cosier, J. \& Glazer, A.M., 1986. J. Appl. Cryst. 105-107.

Fractional atomic coordinates and isotropic or equivalent isotropic displacement parameters $\left(\AA^{2}\right)$

\begin{tabular}{|c|c|c|c|c|}
\hline & $x$ & $y$ & $z$ & $U_{\text {iso }} * / U_{\text {eq }}$ \\
\hline S1 & $0.57630(11)$ & $0.51819(3)$ & $0.79844(6)$ & 0.0223 \\
\hline $\mathrm{C} 2$ & $0.3685(4)$ & $0.48079(13)$ & $0.7529(2)$ & 0.0212 \\
\hline $\mathrm{C} 3$ & $0.2072(4)$ & $0.47646(13)$ & $0.7926(2)$ & 0.0202 \\
\hline S4 & $0.14929(11)$ & $0.50645(3)$ & $0.90297(5)$ & 0.0206 \\
\hline $\mathrm{C} 5$ & $0.3411(4)$ & $0.55384(12)$ & $0.9352(2)$ & 0.0177 \\
\hline C6 & $0.5006(4)$ & $0.55878(12)$ & $0.8951(2)$ & 0.0175 \\
\hline $\mathrm{C} 7$ & $0.6476(4)$ & $0.60247(12)$ & $0.9342(2)$ & 0.0179 \\
\hline O8 & $0.7809(3)$ & $0.61031(9)$ & $0.88850(15)$ & 0.0221 \\
\hline C9 & $0.6255(4)$ & $0.63243(12)$ & $1.0265(2)$ & 0.0167 \\
\hline $\mathrm{C} 10$ & $0.4604(4)$ & $0.62563(12)$ & $1.0704(2)$ & 0.0176 \\
\hline $\mathrm{C} 11$ & $0.3051(4)$ & $0.58862(13)$ & $1.0216(2)$ & 0.0176 \\
\hline $\mathrm{O} 12$ & $0.1533(3)$ & $0.58453(9)$ & $1.05284(15)$ & 0.0237 \\
\hline $\mathrm{C} 13$ & $0.4420(4)$ & $0.65186(13)$ & $1.1586(2)$ & 0.0214 \\
\hline $\mathrm{C} 14$ & $0.5889(5)$ & $0.68550(14)$ & $1.2043(2)$ & 0.0247 \\
\hline $\mathrm{C} 15$ & $0.7515(5)$ & $0.69313(13)$ & $1.1606(2)$ & 0.0235 \\
\hline $\mathrm{C} 16$ & $0.7717(4)$ & $0.66662(13)$ & $1.0719(2)$ & 0.0211 \\
\hline $\mathrm{C} 17$ & $0.0513(5)$ & $0.44419(13)$ & $0.7438(2)$ & 0.0227 \\
\hline N18 & $-0.0763(4)$ & 0.41868 (13) & $0.7075(2)$ & 0.0334 \\
\hline C19 & $0.3871(5)$ & $0.45136(14)$ & $0.6633(2)$ & 0.0244 \\
\hline $\mathrm{N} 20$ & $0.4065(4)$ & $0.42677(13)$ & $0.5922(2)$ & 0.0372 \\
\hline $\mathrm{N} 21$ & $0.1269(3)$ & $0.65896(11)$ & $0.81861(18)$ & 0.0185 \\
\hline $\mathrm{C} 22$ & $0.1456(4)$ & $0.63048(12)$ & $0.7301(2)$ & 0.0193 \\
\hline $\mathrm{C} 23$ & $0.3046(5)$ & $0.63170(13)$ & $0.6818(2)$ & 0.0227 \\
\hline $\mathrm{C} 24$ & $0.3041(5)$ & $0.60183(14)$ & $0.5940(2)$ & 0.0281 \\
\hline $\mathrm{C} 25$ & $0.1478(5)$ & $0.57112(14)$ & $0.5532(2)$ & 0.0305 \\
\hline $\mathrm{C} 26$ & $-0.0103(5)$ & $0.56959(14)$ & $0.6017(2)$ & 0.0289 \\
\hline $\mathrm{C} 27$ & $-0.0132(5)$ & $0.59861(13)$ & $0.6889(2)$ & 0.0227 \\
\hline $\mathrm{C} 28$ & $0.2398(4)$ & $0.69992(12)$ & $0.8710(2)$ & 0.0172 \\
\hline $\mathrm{N} 29$ & $0.4071(3)$ & $0.71395(10)$ & $0.84429(17)$ & 0.0189 \\
\hline $\mathrm{C} 30$ & $0.5047(4)$ & $0.75525(13)$ & $0.8996(2)$ & 0.0204 \\
\hline C31 & $0.4355(4)$ & $0.78043(13)$ & $0.9782(2)$ & 0.0240 \\
\hline
\end{tabular}




$\begin{array}{lllll}\text { C32 } & 0.2624(5) & 0.76203(13) & 1.0009(2) & 0.0233 \\ \text { N33 } & 0.1612(3) & 0.72147(11) & 0.94755(18) & 0.0203 \\ \text { C34 } & 0.1768(5) & 0.78633(16) & 1.0859(3) & 0.0350 \\ \text { C35 } & 0.6919(4) & 0.77160(14) & 0.8698(2) & 0.0256 \\ \text { H131 } & 0.3325 & 0.6473 & 1.1887 & 0.0272^{*} \\ \text { H141 } & 0.5773 & 0.7037 & 1.2645 & 0.0304^{*} \\ \text { H151 } & 0.8471 & 0.7168 & 1.1907 & 0.0275^{*} \\ \text { H161 } & 0.8807 & 0.6722 & 1.0421 & 0.0261^{*} \\ \text { H231 } & 0.4128 & 0.6519 & 0.7083 & 0.0274^{*} \\ \text { H241 } & 0.4121 & 0.6020 & 0.5619 & 0.0339^{*} \\ \text { H251 } & 0.1519 & 0.5519 & 0.4941 & 0.0370^{*} \\ \text { H261 } & -0.1170 & 0.5500 & 0.5748 & 0.0342^{*} \\ \text { H271 } & -0.1197 & 0.5972 & 0.7217 & 0.0260^{*} \\ \text { H311 } & 0.5042 & 0.8085 & 1.0170 & 0.0294^{*} \\ \text { H342 } & 0.0443 & 0.7782 & 1.0832 & 0.0544^{*} \\ \text { H341 } & 0.1920 & 0.8277 & 1.0869 & 0.0549^{*} \\ \text { H343 } & 0.2423 & 0.7710 & 1.1438 & 0.0548^{*} \\ \text { H352 } & 0.7389 & 0.8070 & 0.9003 & 0.0411^{*} \\ \text { H353 } & 0.6847 & 0.7771 & 0.8015 & 0.0418^{*} \\ \text { H351 } & 0.7800 & 0.7420 & 0.8872 & 0.0415^{*} \\ \text { H211 } & 0.022(3) & 0.6531(11) & 0.8421(16) & 0.0231^{*}\end{array}$

Atomic displacement parameters $\left(\AA^{2}\right)$

\begin{tabular}{lllllll}
\hline & $U^{11}$ & $U^{22}$ & $U^{33}$ & $U^{12}$ & $U^{13}$ & $U^{23}$ \\
\hline S1 & 0.0223 & 0.0220 & 0.0224 & -0.0001 & 0.0015 & -0.0055 \\
C2 & 0.0274 & 0.0150 & 0.0197 & 0.0019 & -0.0035 & 0.0014 \\
C3 & 0.0236 & 0.0150 & 0.0203 & -0.0003 & -0.0043 & 0.0020 \\
S4 & 0.0215 & 0.0185 & 0.0211 & -0.0044 & 0.0004 & -0.0018 \\
C5 & 0.0202 & 0.0125 & 0.0189 & 0.0022 & -0.0038 & 0.0041 \\
C6 & 0.0214 & 0.0132 & 0.0169 & 0.0009 & -0.0021 & 0.0022 \\
C7 & 0.0197 & 0.0133 & 0.0204 & 0.0045 & 0.0009 & 0.0041 \\
O8 & 0.0219 & 0.0229 & 0.0214 & -0.0035 & 0.0027 & -0.0011 \\
C9 & 0.0188 & 0.0127 & 0.0171 & 0.0016 & -0.0041 & 0.0010 \\
C10 & 0.0199 & 0.0135 & 0.0184 & 0.0016 & -0.0015 & 0.0037 \\
C11 & 0.0187 & 0.0143 & 0.0198 & 0.0015 & 0.0023 & 0.0054 \\
O12 & 0.0250 & 0.0224 & 0.0244 & -0.0031 & 0.0062 & 0.0008 \\
C13 & 0.0242 & 0.0199 & 0.0206 & 0.0015 & 0.0041 & 0.0008 \\
C14 & 0.0338 & 0.0223 & 0.0175 & -0.0007 & 0.0016 & -0.0052 \\
C15 & 0.0277 & 0.0184 & 0.0225 & -0.0036 & -0.0042 & -0.0039 \\
C16 & 0.0206 & 0.0174 & 0.0244 & 0.0004 & -0.0003 & 0.0021 \\
C17 & 0.0271 & 0.0205 & 0.0195 & -0.0001 & -0.0013 & 0.0002 \\
N18 & 0.0413 & 0.0324 & 0.0255 & -0.0073 & 0.0002 & -0.0019 \\
C19 & 0.0281 & 0.0203 & 0.0244 & 0.0027 & 0.0018 & 0.0001 \\
N20 & 0.0423 & 0.0377 & 0.0314 & 0.0023 & 0.0037 & -0.0076 \\
N21 & 0.0157 & 0.0194 & 0.0204 & -0.0024 & 0.0017 & -0.0019 \\
C22 & 0.0294 & 0.0114 & 0.0161 & 0.0038 & -0.0013 & 0.0021 \\
C23 & 0.0284 & 0.0181 & 0.0215 & 0.0000 & 0.0027 & 0.0018
\end{tabular}


supporting information

\begin{tabular}{lllllll}
$\mathrm{C} 24$ & 0.0429 & 0.0202 & 0.0223 & 0.0053 & 0.0090 & 0.0021 \\
$\mathrm{C} 25$ & 0.0517 & 0.0213 & 0.0177 & 0.0021 & 0.0016 & -0.0017 \\
$\mathrm{C} 26$ & 0.0429 & 0.0167 & 0.0242 & -0.0026 & -0.0075 & -0.0005 \\
C27 & 0.0289 & 0.0183 & 0.0198 & 0.0015 & -0.0020 & 0.0034 \\
C28 & 0.0207 & 0.0113 & 0.0185 & 0.0042 & -0.0016 & 0.0037 \\
N29 & 0.0213 & 0.0152 & 0.0199 & 0.0012 & 0.0007 & 0.0033 \\
C30 & 0.0215 & 0.0145 & 0.0238 & 0.0007 & -0.0033 & 0.0047 \\
C31 & 0.0283 & 0.0158 & 0.0267 & -0.0028 & -0.0013 & -0.0036 \\
C32 & 0.0270 & 0.0190 & 0.0235 & 0.0016 & 0.0019 & -0.0027 \\
N33 & 0.0224 & 0.0175 & 0.0210 & 0.0013 & 0.0029 & -0.0031 \\
C34 & 0.0366 & 0.0326 & 0.0373 & -0.0031 & 0.0103 & -0.0140 \\
C35 & 0.0244 & 0.0239 & 0.0278 & -0.0050 & 0.0004 & 0.0034 \\
\hline
\end{tabular}

Geometric parameters $\left(\AA,{ }^{\circ}\right)$

\begin{tabular}{|c|c|c|c|}
\hline $\mathrm{S} 1-\mathrm{C} 2$ & $1.764(3)$ & $\mathrm{N} 21-\mathrm{H} 211$ & $0.864(17)$ \\
\hline $\mathrm{S} 1-\mathrm{C} 6$ & $1.764(3)$ & $\mathrm{C} 22-\mathrm{C} 23$ & $1.391(4)$ \\
\hline $\mathrm{C} 2-\mathrm{C} 3$ & $1.343(4)$ & $\mathrm{C} 22-\mathrm{C} 27$ & $1.410(4)$ \\
\hline $\mathrm{C} 2-\mathrm{C} 19$ & $1.429(4)$ & $\mathrm{C} 23-\mathrm{C} 24$ & $1.390(4)$ \\
\hline $\mathrm{C} 3-\mathrm{S} 4$ & $1.767(3)$ & $\mathrm{C} 23-\mathrm{H} 231$ & 0.938 \\
\hline $\mathrm{C} 3-\mathrm{C} 17$ & $1.436(4)$ & $\mathrm{C} 24-\mathrm{C} 25$ & $1.382(5)$ \\
\hline $\mathrm{S} 4-\mathrm{C} 5$ & $1.763(3)$ & $\mathrm{C} 24-\mathrm{H} 241$ & 0.939 \\
\hline $\mathrm{C} 5-\mathrm{C} 6$ & $1.336(4)$ & $\mathrm{C} 25-\mathrm{C} 26$ & $1.387(5)$ \\
\hline $\mathrm{C} 5-\mathrm{C} 11$ & $1.483(4)$ & $\mathrm{C} 25-\mathrm{H} 251$ & 0.930 \\
\hline $\mathrm{C} 6-\mathrm{C} 7$ & $1.502(4)$ & $\mathrm{C} 26-\mathrm{C} 27$ & $1.378(4)$ \\
\hline $\mathrm{C} 7-\mathrm{O} 8$ & $1.223(4)$ & $\mathrm{C} 26-\mathrm{H} 261$ & 0.923 \\
\hline $\mathrm{C} 7-\mathrm{C} 9$ & $1.473(4)$ & $\mathrm{C} 27-\mathrm{H} 271$ & 0.936 \\
\hline $\mathrm{C} 9-\mathrm{C} 10$ & $1.404(4)$ & $\mathrm{C} 28-\mathrm{N} 29$ & $1.336(4)$ \\
\hline $\mathrm{C} 9-\mathrm{C} 16$ & $1.393(4)$ & $\mathrm{C} 28-\mathrm{N} 33$ & $1.350(4)$ \\
\hline $\mathrm{C} 10-\mathrm{C} 11$ & $1.491(4)$ & $\mathrm{N} 29-\mathrm{C} 30$ & $1.353(4)$ \\
\hline $\mathrm{C} 10-\mathrm{C} 13$ & $1.379(4)$ & $\mathrm{C} 30-\mathrm{C} 31$ & $1.375(4)$ \\
\hline $\mathrm{C} 11-\mathrm{O} 12$ & $1.222(4)$ & $\mathrm{C} 30-\mathrm{C} 35$ & $1.499(4)$ \\
\hline $\mathrm{C} 13-\mathrm{C} 14$ & $1.390(4)$ & $\mathrm{C} 31-\mathrm{C} 32$ & $1.382(5)$ \\
\hline $\mathrm{C} 13-\mathrm{H} 131$ & 0.938 & $\mathrm{C} 31-\mathrm{H} 311$ & 0.935 \\
\hline $\mathrm{C} 14-\mathrm{C} 15$ & $1.388(5)$ & $\mathrm{C} 32-\mathrm{N} 33$ & $1.339(4)$ \\
\hline C14-H141 & 0.944 & $\mathrm{C} 32-\mathrm{C} 34$ & $1.498(4)$ \\
\hline $\mathrm{C} 15-\mathrm{C} 16$ & $1.390(4)$ & C34-H342 & 0.964 \\
\hline $\mathrm{C} 15-\mathrm{H} 151$ & 0.931 & $\mathrm{C} 34-\mathrm{H} 341$ & 0.950 \\
\hline $\mathrm{C} 16-\mathrm{H} 161$ & 0.936 & $\mathrm{C} 34-\mathrm{H} 343$ & 0.944 \\
\hline C17-N18 & $1.146(4)$ & $\mathrm{C} 35-\mathrm{H} 352$ & 0.952 \\
\hline $\mathrm{C} 19-\mathrm{N} 20$ & $1.155(4)$ & $\mathrm{C} 35-\mathrm{H} 353$ & 0.949 \\
\hline $\mathrm{N} 21-\mathrm{C} 22$ & $1.406(4)$ & $\mathrm{C} 35-\mathrm{H} 351$ & 0.935 \\
\hline $\mathrm{N} 21-\mathrm{C} 28$ & $1.382(4)$ & & \\
\hline $\mathrm{C} 2-\mathrm{S} 1-\mathrm{C} 6$ & $101.45(14)$ & $\mathrm{N} 21-\mathrm{C} 22-\mathrm{C} 27$ & $115.5(3)$ \\
\hline $\mathrm{S} 1-\mathrm{C} 2-\mathrm{C} 3$ & $128.4(2)$ & $\mathrm{C} 23-\mathrm{C} 22-\mathrm{C} 27$ & $119.0(3)$ \\
\hline $\mathrm{S} 1-\mathrm{C} 2-\mathrm{C} 19$ & $111.8(2)$ & $\mathrm{C} 22-\mathrm{C} 23-\mathrm{C} 24$ & $119.6(3)$ \\
\hline $\mathrm{C} 3-\mathrm{C} 2-\mathrm{C} 19$ & $119.7(3)$ & $\mathrm{C} 22-\mathrm{C} 23-\mathrm{H} 231$ & 120.6 \\
\hline
\end{tabular}




\begin{tabular}{|c|c|c|c|}
\hline $\mathrm{C} 2-\mathrm{C} 3-\mathrm{S} 4$ & $129.0(2)$ & $\mathrm{C} 24-\mathrm{C} 23-\mathrm{H} 231$ & 119.7 \\
\hline $\mathrm{C} 2-\mathrm{C} 3-\mathrm{C} 17$ & $120.4(3)$ & $\mathrm{C} 23-\mathrm{C} 24-\mathrm{C} 25$ & $121.3(3)$ \\
\hline $\mathrm{S} 4-\mathrm{C} 3-\mathrm{C} 17$ & $110.6(2)$ & $\mathrm{C} 23-\mathrm{C} 24-\mathrm{H} 241$ & 119.7 \\
\hline $\mathrm{C} 3-\mathrm{S} 4-\mathrm{C} 5$ & $101.35(14)$ & $\mathrm{C} 25-\mathrm{C} 24-\mathrm{H} 241$ & 118.9 \\
\hline $\mathrm{S} 4-\mathrm{C} 5-\mathrm{C} 6$ & $128.9(2)$ & $\mathrm{C} 24-\mathrm{C} 25-\mathrm{C} 26$ & $119.0(3)$ \\
\hline $\mathrm{S} 4-\mathrm{C} 5-\mathrm{C} 11$ & $108.9(2)$ & $\mathrm{C} 24-\mathrm{C} 25-\mathrm{H} 251$ & 119.1 \\
\hline $\mathrm{C} 6-\mathrm{C} 5-\mathrm{C} 11$ & $122.2(3)$ & $\mathrm{C} 26-\mathrm{C} 25-\mathrm{H} 251$ & 121.9 \\
\hline $\mathrm{S} 1-\mathrm{C} 6-\mathrm{C} 5$ & $129.0(2)$ & $\mathrm{C} 25-\mathrm{C} 26-\mathrm{C} 27$ & $120.8(3)$ \\
\hline $\mathrm{S} 1-\mathrm{C} 6-\mathrm{C} 7$ & $110.7(2)$ & $\mathrm{C} 25-\mathrm{C} 26-\mathrm{H} 261$ & 120.2 \\
\hline $\mathrm{C} 5-\mathrm{C} 6-\mathrm{C} 7$ & $120.3(3)$ & $\mathrm{C} 27-\mathrm{C} 26-\mathrm{H} 261$ & 118.9 \\
\hline $\mathrm{C} 6-\mathrm{C} 7-\mathrm{O} 8$ & $118.0(3)$ & $\mathrm{C} 22-\mathrm{C} 27-\mathrm{C} 26$ & $120.2(3)$ \\
\hline $\mathrm{C} 6-\mathrm{C} 7-\mathrm{C} 9$ & $118.3(3)$ & $\mathrm{C} 22-\mathrm{C} 27-\mathrm{H} 271$ & 119.3 \\
\hline $\mathrm{O} 8-\mathrm{C} 7-\mathrm{C} 9$ & $123.6(3)$ & $\mathrm{C} 26-\mathrm{C} 27-\mathrm{H} 271$ & 120.5 \\
\hline $\mathrm{C} 7-\mathrm{C} 9-\mathrm{C} 10$ & $120.6(3)$ & $\mathrm{N} 21-\mathrm{C} 28-\mathrm{N} 29$ & $120.3(3)$ \\
\hline $\mathrm{C} 7-\mathrm{C} 9-\mathrm{C} 16$ & $119.7(3)$ & $\mathrm{N} 21-\mathrm{C} 28-\mathrm{N} 33$ & $112.5(3)$ \\
\hline $\mathrm{C} 10-\mathrm{C} 9-\mathrm{C} 16$ & $119.7(3)$ & $\mathrm{N} 29-\mathrm{C} 28-\mathrm{N} 33$ & $127.2(3)$ \\
\hline $\mathrm{C} 9-\mathrm{C} 10-\mathrm{C} 11$ & $119.3(3)$ & $\mathrm{C} 28-\mathrm{N} 29-\mathrm{C} 30$ & $115.5(3)$ \\
\hline $\mathrm{C} 9-\mathrm{C} 10-\mathrm{C} 13$ & $120.7(3)$ & $\mathrm{N} 29-\mathrm{C} 30-\mathrm{C} 31$ & $121.7(3)$ \\
\hline $\mathrm{C} 11-\mathrm{C} 10-\mathrm{C} 13$ & $119.9(3)$ & $\mathrm{N} 29-\mathrm{C} 30-\mathrm{C} 35$ & $115.9(3)$ \\
\hline $\mathrm{C} 10-\mathrm{C} 11-\mathrm{C} 5$ & $118.2(3)$ & $\mathrm{C} 31-\mathrm{C} 30-\mathrm{C} 35$ & $122.4(3)$ \\
\hline $\mathrm{C} 10-\mathrm{C} 11-\mathrm{O} 12$ & $122.1(3)$ & $\mathrm{C} 30-\mathrm{C} 31-\mathrm{C} 32$ & $118.3(3)$ \\
\hline $\mathrm{C} 5-\mathrm{C} 11-\mathrm{O} 12$ & $119.6(3)$ & С $30-\mathrm{C} 31-\mathrm{H} 311$ & 121.5 \\
\hline $\mathrm{C} 10-\mathrm{C} 13-\mathrm{C} 14$ & $119.5(3)$ & $\mathrm{C} 32-\mathrm{C} 31-\mathrm{H} 311$ & 120.2 \\
\hline $\mathrm{C} 10-\mathrm{C} 13-\mathrm{H} 131$ & 121.3 & $\mathrm{C} 31-\mathrm{C} 32-\mathrm{N} 33$ & $121.7(3)$ \\
\hline $\mathrm{C} 14-\mathrm{C} 13-\mathrm{H} 131$ & 119.3 & $\mathrm{C} 31-\mathrm{C} 32-\mathrm{C} 34$ & $122.1(3)$ \\
\hline $\mathrm{C} 13-\mathrm{C} 14-\mathrm{C} 15$ & $120.1(3)$ & $\mathrm{N} 33-\mathrm{C} 32-\mathrm{C} 34$ & $116.2(3)$ \\
\hline $\mathrm{C} 13-\mathrm{C} 14-\mathrm{H} 141$ & 120.0 & $\mathrm{C} 28-\mathrm{N} 33-\mathrm{C} 32$ & $115.6(3)$ \\
\hline $\mathrm{C} 15-\mathrm{C} 14-\mathrm{H} 141$ & 119.9 & $\mathrm{C} 32-\mathrm{C} 34-\mathrm{H} 342$ & 113.2 \\
\hline $\mathrm{C} 14-\mathrm{C} 15-\mathrm{C} 16$ & $120.9(3)$ & $\mathrm{C} 32-\mathrm{C} 34-\mathrm{H} 341$ & 108.8 \\
\hline $\mathrm{C} 14-\mathrm{C} 15-\mathrm{H} 151$ & 119.4 & $\mathrm{H} 342-\mathrm{C} 34-\mathrm{H} 341$ & 107.6 \\
\hline $\mathrm{C} 16-\mathrm{C} 15-\mathrm{H} 151$ & 119.7 & $\mathrm{C} 32-\mathrm{C} 34-\mathrm{H} 343$ & 108.7 \\
\hline $\mathrm{C} 9-\mathrm{C} 16-\mathrm{C} 15$ & $119.1(3)$ & $\mathrm{H} 342-\mathrm{C} 34-\mathrm{H} 343$ & 110.3 \\
\hline C9-C16-H161 & 120.1 & $\mathrm{H} 341-\mathrm{C} 34-\mathrm{H} 343$ & 108.1 \\
\hline $\mathrm{C} 15-\mathrm{C} 16-\mathrm{H} 161$ & 120.8 & $\mathrm{C} 30-\mathrm{C} 35-\mathrm{H} 352$ & 111.7 \\
\hline $\mathrm{C} 3-\mathrm{C} 17-\mathrm{N} 18$ & $177.7(3)$ & $\mathrm{C} 30-\mathrm{C} 35-\mathrm{H} 353$ & 111.4 \\
\hline $\mathrm{C} 2-\mathrm{C} 19-\mathrm{N} 20$ & $178.1(3)$ & $\mathrm{H} 352-\mathrm{C} 35-\mathrm{H} 353$ & 107.6 \\
\hline $\mathrm{C} 22-\mathrm{N} 21-\mathrm{C} 28$ & $131.0(3)$ & $\mathrm{C} 30-\mathrm{C} 35-\mathrm{H} 351$ & 110.5 \\
\hline $\mathrm{C} 22-\mathrm{N} 21-\mathrm{H} 211$ & $115.8(12)$ & $\mathrm{H} 352-\mathrm{C} 35-\mathrm{H} 351$ & 107.8 \\
\hline $\mathrm{C} 28-\mathrm{N} 21-\mathrm{H} 211$ & $112.8(12)$ & $\mathrm{H} 353-\mathrm{C} 35-\mathrm{H} 351$ & 107.7 \\
\hline $\mathrm{N} 21-\mathrm{C} 22-\mathrm{C} 23$ & $125.5(3)$ & & \\
\hline
\end{tabular}

Hydrogen-bond geometry $\left(\AA,{ }^{\circ}\right)$

\begin{tabular}{lllll}
\hline$D-\mathrm{H} \cdots A$ & $D-\mathrm{H}$ & $\mathrm{H} \cdots A$ & $D \cdots A$ & $D-\mathrm{H} \cdots A$ \\
\hline $\mathrm{C} 23-\mathrm{H} 231 \cdots \mathrm{N} 29$ & 0.94 & 2.36 & $2.950(4)$ & $121(1)$
\end{tabular}


supporting information

$\mathrm{C} 27-\mathrm{H} 271 \cdots \mathrm{O} 8$

$\mathrm{N} 21-\mathrm{H} 211 \cdots \mathrm{O}^{\mathrm{i}}$

Symmetry code: (i) $x-1, y, z$.
0.94

0.86
2.51

2.15
$3.296(4)$

$2.985(4)$
$141(1)$

$162(2)$ 